\title{
Debt Relief for Low-Income Countries \\ The HIPC Initiative
}

Anthony R. Boote and Kamau Thugge

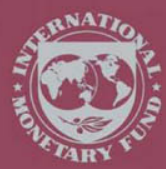

INTERNATIONAL MONETARY FUND

Washington, D.C.

1999 


\section{Debt Relief for Low-Income Countries \\ The HIPC Initiative}

Anthony R. Boote and Kamau Thugge

INTERNATIONAL MONETARY FUND

Washington, D.C.

1999

(C) International Monetary Fund. Not for Redistribution 
Revised February 1999

Reprinted May 1999

ISSN 0538-8759

ISBN 1-55775-661-9

Production: IMF Graphics Section

Cover design: Luisa Menjivar-Macdonald

Figures: In-Ok Yoon

Typesetting: Alicia Etchebarne-Bourdin 


\section{Contents}

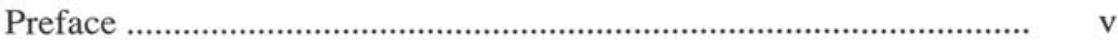

Traditional Debt-Relief Mechanisms for HIPCs ………………….... 2

Paris Club Creditors ......................................................................... 4

Commercial and Non-Paris Club Bilateral Creditors .................... $\quad 5$

Multilateral Creditors …….......................................................... 6

Positive Net Resource Transfers and New Financing

on Concessional Terms ………………………………...........

The HIPC Initiative ……………………………………................. 8

Main Objectives of the HIPC Initiative ………………………..... 9

Some Key Features of the HIPC Initiative .................................... 10

Key Steps in Implementing the HIPC Initiative …………........... 13

Progress Made in the HIPC Initiative ……………………………. 15

Conclusion ……................................................................. 16

Annex. The HIPC Initiative …………………………................ 18

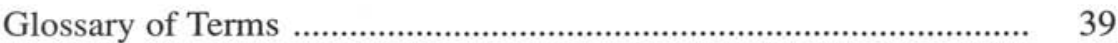

Box

Paris Club Naples Terms ……………................................... 6

Tables

1. Status of Paris Club Rescheduling Countries ………............ 22

2. HIPCs: Indicators of External Debt Burden ............................ 24

3. HIPCs: Characteristics of Existing External Debt ................... 28

4. Evolution of Paris Club Rescheduling Terms .......................... $\quad 30$

5. Commercial Bank Debt- and Debt-Service-Reduction

Operations, 1987-March 1997 ....................................... 32

6. HIPCs: Net Disbursements from Multilateral Institutions ....... 34

7. HIPCs: Net Concessional Flows, Debt Service Due and Paid ............................................................ $\quad 36$

8. HIPC Initiative: Status of Country Cases, September 1998 ..... 38

Figures

1. Developing Countries: Public External Debt by Creditor 3

2. The HIPC Initiative: Summary ............................................ 12 
The following symbols have been used throughout this pamphlet:

... to indicate that data are not available;

- to indicate that the figure is zero or less than half the final digit shown, or that the item does not exist;

- between years or months (e.g., 1996-97 or January-June) to indicate the years or months covered, including the beginning and ending years or months;

/ between years (e.g., 1996/97) to indicate a crop or fiscal (financial) year.

"Billion" means a thousand million.

Minor discrepancies between constituent figures and totals are due to rounding.

The term "country," as used in this pamphlet, does not in all cases refer to a territorial entity that is a state as understood by international law and practice; the term also covers some territorial entities that are not states, but for which statistical data are maintained and provided internationally on a separate and independent basis. 


\section{Preface}

Since the onset of the debt crisis in the early 1980s, many heavily indebted poor countries (HIPCs) continue to have difficulty in paying their external debt-service obligations, largely because of exogenous factors, imprudent debt-management policies, and the lack of sustained adjustment or implementation of structural reforms. The international community over the past decade has implemented a wide range of traditional mechanisms destined to provide needed external finance and alleviate the debt burden of these countries. While these traditional mechanisms are sufficient to reduce the external debts of many HIPCs to sustainable levels provided these countries implement sound economic policies, they are likely to be insufficient for a number of countries. To deal with these cases, the World Bank and the IMF have jointly proposed and put in place the HIPC Initiative; the goal is to reduce the debt burdens of all eligible HIPCs to sustainable levels.

This pamphlet describes the HIPC Initiative and suggests that it should enable HIPCs to exit from the debt-rescheduling process. It argues that implementation of the Initiative should eliminate debt as an impediment to economic development and growth and enable HIPC governments to focus on the difficult policies and reforms required to remove the remaining impediments to achieving sustainable development. It describes the implementation of the Initiative through the end of September 1998.

The authors would like to thank Jack Boorman, Doris Ross, and Christina Daseking, of the IMF's Policy Development and Review Department, and Fred Kilby and Axel van Trotsenburg of the World Bank, for helpful comments. Barbara Dabrowska provided valuable statistical help, and Sulochana Kamaldinni typed numerous drafts as well as the final version of the pamphlet with her customary patience and efficiency. Thanks are also due to Esha Ray of the External Relations Department for her editorial assistance.

The opinions expressed in the pamphlet are those of the authors and do not necessarily reflect the views of the IMF or of its Executive Directors. 
This page intentionally left blank 


\section{Debt Relief for Low-Income Countries}

\section{The HIPC Initiative}

The HIPC Initiative is a framework developed jointly by the IMF and the World Bank to address the external debt problems of the heavily indebted poor countries (HIPCs). It is based on the following guiding principles: (1) the objective is to target overall debt sustainability on a case-by-case basis, focusing on the totality of a country's debt; (2) actions should be envisaged only when the debtor has shown, through a track record, ability to put to good use the exceptional support provided; (3) the new measures should build, as much as possible, on existing mechanisms; (4) additional action should be coordinated among all creditors involved, with broad and equitable participation; (5) action by multilateral creditors should preserve their financial integrity and preferred creditor status; and (6) new external finance for the indebted countries should be on appropriately concessional terms.

Since the onset of the debt crisis in the early 1980s, which affected both middle- and low-income countries, the debt situation of middle-income debtor countries has improved significantly. Many of these countries have benefited from concerted support by the international financial community. This support has been provided in the form of Paris Club flow reschedulings (Table 1), stock-of-debt arrangements under the Brady plan, and adjustment programs supported by the multilateral financial institutions. These instruments have proved to be effective mechanisms for allowing countries to normalize relations with external creditors and to resume sustainable growth. Recent years have witnessed a reentry to international capital markets by many middle-income countries that had been most severely affected by the debt crisis.

However, the HIPCs, most of which are in sub-Saharan Africa, have continued to find it difficult to meet their external debt-service obligations. The difficulties can be traced to a combination of several factors. These include (1) external shocks, such as a deterioration in the terms of trade, and adverse weather conditions; (2) civil strife; (3) the lack of sustained adjustment or implementation of structural reforms; (4) the lending policies of many creditors, especially the provision of loans on commercial interest 
rates with short repayment periods; (5) the lack of prudent debt-management policies by debtor countries, driven in part by excessive optimism by creditors and debtors about the prospects for increasing export earnings to build debt-servicing capacity; and (6) the lack of careful management of the currency composition of external debt. All these factors contributed to increasing the debt burden of the HIPCs.

In several important respects, the external position of the HIPCs differs widely from country to country (Table 2). For example, in 1994, for some HIPCs the external current account was in surplus, while for others deficits exceeded 100 percent of exports. In addition, scheduled debt-service obligations varied widely - from less than 20 percent of exports for some countries to more than 100 percent for others, while the actual debt service paid ranged from 5 percent of exports to as much as 50 percent. Finally, the HIPCs are indebted to a variety of creditors, including Paris Club bilateral creditors, non-Paris Club bilateral creditors, commercial banks, and multilateral institutions (Table 3 and Figure 1).

Recognizing the highly varied external positions among the HIPCs, the international financial community has addressed the debt problems of these countries in a manner that takes into account the total debt of the country concerned and ensures that debt relief is given in support of adjustment by debtors on a case-by-case basis, tailored to the individual circumstances of each debtor country.

\section{Traditional Debt-Relief Mechanisms for HIPCs}

To address the debt burden of the low-income countries, the international financial community (including Paris Club creditors, non-Paris Club bilateral and commercial creditors, and multilateral institutions) has over the past decade introduced and implemented a wide range of traditional mechanisms to alleviate the debt burden of these countries. In general, the main trend has been a move toward increasing the concessional element of the external assistance provided to the low-income countries.

The traditional mechanisms can be summarized as follows: (1) the adoption of stabilization and economic reform programs supported by concessional loans from the IMF and the World Bank; (2) in support of these adjustment programs, flow-rescheduling agreements with Paris Club creditors on concessional terms followed by a stock-of-debt operation after three years of good track records under both IMF arrangements and 
FIGURE 1. DEVELOPING COUNTRIES:

PUBLIC EXTERNAL DEBT bY CREDITOR

(In billions of U.S. dollars)

\section{$\square$ Multilateral creditors $\square$ Official bilateral creditors $\square$ Private creditors (left scale) (left scale) (left scale)}

All developing countries

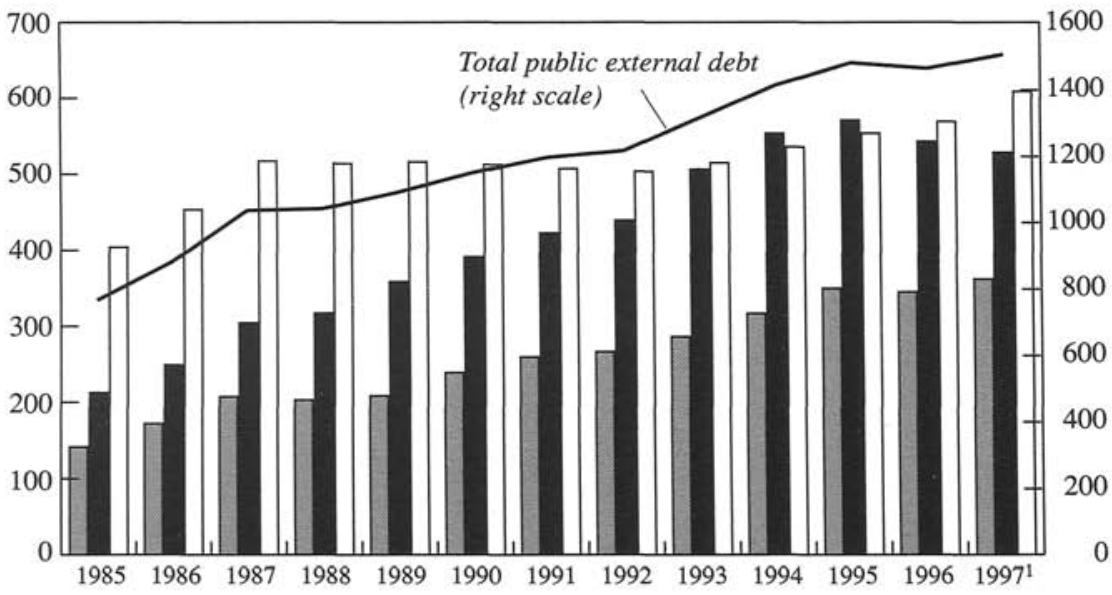

Low-income countries

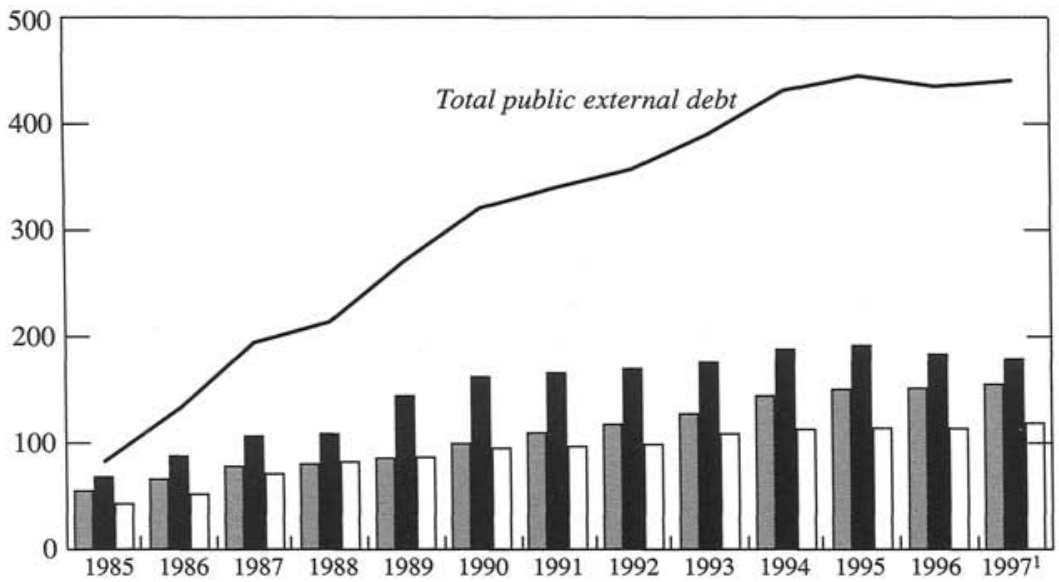

Sources: World Bank Debtor Reporting System; and IMF, International Financial Statistics. Note: Medium- and long-term public and publicly guaranteed debt, including to the IMF. ${ }^{1}$ The estimates for 1997 are provisional. 
rescheduling agreements; (3) agreement by the debtor country to seek at least comparable terms on debt owed to non-Paris Club bilateral and commercial creditors facilitated by International Development Association (IDA) debt-reduction operations on commercial debt; (4) bilateral forgiveness of official development assistance debt by many creditors; and (5) new financing on appropriately concessional terms.

This process has significant advantages in that it ensures that new concessional financing and debt relief both under flow reschedulings (directly) and under stock-of-debt operations (via the required track record) are given in support of an adjustment effort by the debtor. Moreover, the process provides for a case-by-case treatment of individual debtors-reflecting, as noted above, their widely different external positions-both by creditors (with Paris Club creditors tailoring effective debt relief to financing needs) and by donors (in the consultative group process).

\section{Paris Club Creditors}

In the early 1980 s, Paris Club creditors provided reschedulings for lowincome countries on nonconcessional standard terms with relatively short grace (five years) and maturity (ten years) periods and on market-related interest rates. Although the reschedulings for the low-income countries were more comprehensive in coverage and provided for more cash relief than for other debtors, many of these countries continued to have difficulties adhering to the resulting repayment schedules. Consequently, the rescheduling of interest led to rapid accumulation of debt. By the late 1980s, Paris Club creditors recognized that repeated reschedulings on standard terms over a prolonged period would not solve the debt problems of the low-income countries and that most of these countries needed not only cash-flow relief but also reductions of debt. Thus, in late 1988, Paris Club creditors agreed to provide concessional reschedulings for low-income countries on Toronto terms, a menu of options for debt and debt-service reduction to reduce the net present value (NPV) of rescheduled amounts by up to one third (Table 4). Although these reschedulings provided for substantial debt reduction, it became increasingly obvious that for many low-income countries more far-reaching concessions would be needed if their debt situation was to be improved on a durable basis.

Thus, in December 1991, creditors introduced London terms and increased the level of debt relief on eligible debt in NPV terms to 50 percent. Subsequently, in December 1994, the level of concessionality for 
most countries was again increased to 67 percent of eligible debt in NPV terms under Naples terms (see Box). Under both London and Naples terms, the flow-rescheduling agreements included a goodwill clause, in which participating creditor countries agreed to consider a stock-of-debt operation for countries that had established a good track record of performance for at least three years under an IMF-supported program and on debt-service payments to Paris Club creditors. Such a stock-of-debt operation was viewed as an "exit rescheduling," and creditors had to be confident that the debtor country would be able to meet future debt-service obligations without the need for additional debt relief. Since early 1995, six countries (Benin, Bolivia, Burkina Faso, Guyana, Mali, and Uganda) have agreed comprehensive stock-of-debt operations with Paris Club creditors under Naples terms.

In September 1997, agreement was reached between Russia and Paris Club creditors on the basis for Russia's participation in the Paris Club reschedulings as a creditor. This agreement provides that Russian claims inherited from the former Soviet Union will be reduced by an upfront discount, with a higher discount applied to claims on the poorest countries (eligible for Naples terms). After this discount, Russia will apply debt reduction or debt relief on the same basis as other Paris Club creditors. This agreement is expected to facilitate the regularization of financial relations between many developing countries and Russia.

\section{Commercial and Non-Paris Club Bilateral Creditors}

To ensure concerted support by the international community, Paris Club rescheduling agreements include a comparability clause under which the rescheduling country commits itself to seek at least comparable debt relief from commercial and non-Paris Club bilateral creditors. The clause is intended to ensure equitable burden sharing among the various categories of creditors. In addition, in recent years, low-income countries were able to buy back most of their debt to private creditors that was being traded in the secondary market at a large discount from the face value using funds from the Debt Reduction Facility of IDA and from bilateral donors (Table 5).

With respect to official creditors outside the Paris Club, there has been little progress in normalizing relations between creditors and debtors. ${ }^{1}$

${ }^{1}$ Major non-Paris Club bilateral creditors include China, Kuwait, the Libyan Arab Jamahiriya, and Saudi Arabia. Kuwait sometimes participates in Paris Club reschedulings. 


\section{Paris Club Naples Terms}

Key elements of Naples terms, which at end-1994 replaced the previous concessional (Toronto or London) terms, for low-income countries are as follows.

- Eligibility. Decided by creditors on a case-by-case basis, based primarily on a country's income level. Countries that have previously received concessional reschedulings (on Toronto or London terms) are eligible for Naples terms.

- Concessionality. Most countries receive a reduction in eligible nonofficial development assistance (ODA) debt of 67 percent in net present value (NPV) terms. Some countries with a per capita income of more than $\$ 500$ and a ratio of debt to exports in present value terms of less than 350 percent-decided on a case-by-case basis-receive a 50 percent NPV reduction.

- Coverage. The coverage (inclusion in the rescheduling agreement) of nonODA pre-cutoff date debt is decided on a case-by-case basis in the light of balance of payments needs. Debt previously rescheduled on concessional (either Toronto or London) terms is potentially subject to further rescheduling, to top up the amount of concessionality given. ${ }^{1}$

- Choice of options. Creditors have a choice of two concessional options for achieving a 67 percent (or 50 percent) NPV reduction, ${ }^{2}$ namely

A debt reduction (DR) option (repayment over 23 years with 6 years' grace), or

'Under such topping up, the NPV reduction is increased from the original level given under Toronto or London terms to the new level agreed under Naples terms, namely 67 percent or 50 percent.

${ }^{2}$ For a 50 percent NPV reduction, the debt-service reduction option provides for repayment over 23 years with 6 years' grace and the long-maturities option for repayment over 25 years with 16 years' grace.

\section{Multilateral Creditors}

Multilateral creditors have participated in the efforts of the international community by helping debtor countries to design and implement adjustment and structural reform programs that have been supported by concessional loans from the IMF and the World Bank. Multilateral financing over the past decade shows three major trends: (1) the share of multilateral debt in the total for HIPCs has increased as multilaterals continued to make large-scale contributions to the financing of these countries; (2) increasingly, financing 
A debt-service reduction (DSR) option, under which the NPV reduction is achieved by concessional interest rates (with repayment over 33 years). ${ }^{3,4}$

There is also a commercial or long maturities (LM) option, providing for no NPV reduction (repayment over 40 years with 20 years' grace). ${ }^{5}$

- ODA credits. Pre-cutoff date credits are rescheduled on interest rates at least as concessional as the original interest rates over 40 years with 16 years' grace ( 30 years' maturity with 12 years' grace for 50 percent NPV reduction). 6

- Flow reschedulings provide for the rescheduling of debt service on eligible debt falling due during the consolidation period (generally in line with the period of the IMF arrangement).

- Stock-of-debt operations, under which the entire stock of eligible pre-cutoff date debt is rescheduled concessionally, are reserved for countries with a satisfactory track record for a minimum of three years with respect to both payments under rescheduling agreements and performance under IMF arrangements. Creditors must be confident that the country will be able to respect the debt agreement as an exit rescheduling (with no further reschedulings required) and there must be a consensus among creditors to choose concessional options.

${ }^{3}$ For flow reschedulings, there is no grace period, and for stock-of-debt operations the grace period is three years.

${ }^{4}$ There is, in addition, a capitalization of moratorium interest (CMI) option, which also achieves the NPV reduction by a lower interest rate over the same repayment (and grace) periods as the DSR option.

${ }^{5}$ Creditors choosing this option undertake best efforts to change to a concessional option at a later date when feasible.

${ }^{6}$ Creditors can also choose an option reducing the NPV of ODA debt by 67 (or 50) percent.

has been provided on concessional terms, especially from the IMF (first under the Structural Adjustment Facility (SAF) and then under the Enhanced Structural Adjustment Facility (ESAF)) and the World Bank (through IDA including supplemental credits under the Fifth Dimension Facility, which provides financial support to IDA-only eligible countries ${ }^{2}$ with outstanding IBRD debts to cover part of their interest obligations on these

${ }^{2}$ That is, countries that receive funds from IDA but not from the International Bank for Reconstruction and Development (IBRD). 
loans) providing de facto debt relief as more expensive debt (such as nonconcessional exposure to the IMF) was replaced by concessional debt (such as ESAF); and (3) despite the increase in multilateral debt to the HIPCs, debt-service payments on multilateral debt have remained relatively stable at about $81 / 2$ percent of exports each year during 1985-95, reflecting the increased concessionality of loans. ${ }^{3}$

\section{Positive Net Resource Transfers and New Financing on Concessional Terms}

It is important to note that the amounts of grants and new loan disbursements from the creditor/donor community to most HIPCs have exceeded actual debt-service payments on interest and amortization and as a result net transfers were positive. For example, multilaterals as a group have provided to the 41 HIPCs positive net disbursements averaging over $\$ 3$ billion a year from 1990 to 1996 and positive net transfers averaging about $\$ 1.5$ billion a year over the same period (Table 6). Official bilateral creditors and donors have, through such forums as Consultative Group meetings and the Special Program of Assistance for Sub-Saharan Africa, provided new concessional financing in the form of grants or highly concessional loans partly to meet the financing requirements identified under adjustment programs. Thus in 1994, inflows of grants and concessional assistance from official donors were more than three times actual debt service paid. During 1990-94, net resource flows (gross flows less principal repayments) including bilateral grants to HIPCs have averaged around 8 percent of GNP (Table 7).

\section{The HIPC Initiative}

The traditional mechanisms for dealing with the debt problems of low-income countries are sufficiently robust to deal with the debt burden of many HIPCs and to reduce their external debts to sustainable levels (see definition below). As noted earlier, the external positions of the HIPCs vary widely and indeed some countries such as Ghana, Kenya, and the Lao People's Democratic Republic have never received concessional reschedulings from the

${ }^{3}$ According to the World Bank's Debtor Reporting System, the ratio rose to $11 \frac{1}{2}$ percent in 1995 reflecting the clearance of Zambia's arrears to the IMF. Excluding Zambia, it remained at about 8 percent in 1995 . 
Paris Club. Others, such as Equatorial Guinea and Vietnam, are unlikely to need the full use of traditional debt-relief mechanisms in order to reach debt levels that are sustainable. However, even with sound economic policies and full use of traditional mechanisms for rescheduling and debt reduction and the continued provision of concessional financing, a number of countries are not expected to reach sustainable levels of debt within a reasonable period of time. To deal with this problem, the IMF and World Bank jointly proposed and put in place in September 1996 the HIPC Initiative that aims at reducing the debt burdens of all eligible HIPCs to sustainable levels, provided they adopt and pursue strong programs of adjustment and reform. The Initiative builds on instruments available to the international community to deal decisively with the debt problems of the low-income countries and allows them to exit, once and for all, from the rescheduling process.

An important benefit of exiting from the rescheduling process is a return to normal relations with the international financial community, characterized by spontaneous financial flows and the full honoring of commitments. In addition, repeated reschedulings involve significant costs for policymakers and create uncertainty about future debt relief and may foster the belief on the part of borrowers that financial contracts need not be honored. The Initiative would also reduce what is known as the "debt overhang," namely the negative impact of a large external debt burden on economic growth. A debt overhang can contribute to investment disincentives, and could delay private capital flows required to generate sustainable growth. The HIPCs face a host of formidable challenges, of which the debt burden is only one problem. However, the removal of the debt overhang by implementing the HIPC Initiative will permit these countries to focus on the policies required to tackle other impediments to sustainable growth, such as inadequate physical infrastructure, untrained workforces, and weak institutions.

\section{Main Objectives of the HIPC Initiative}

The Initiative is intended to deal in a comprehensive manner with the overall debt burden of eligible countries and to reduce it to a sustainable level within a reasonable period of time. The Initiative involves a commitment made at the decision point-after a three-year track record-by the international financial community to provide sufficient debt relief to reduce the debt burden of eligible countries to sustainable levels, provided the country completes a further three-year period of strong policy performance. 
A country can be considered to achieve external debt sustainability if it is expected to be able to meet its current and future external debt-service obligations in full, without recourse to debt relief, rescheduling of debts, or the accumulation of arrears, and without unduly compromising growth. Key indicators of external debt sustainability include the NPV of debt-toexports ratio and the debt-service ratio. On the basis of experience of a large number of countries, target ranges for determining debt sustainability have been established. Sustainable debt levels under the Initiative will be defined on a case-by-case basis within the range of 200 percent to 250 percent for the debt-to-exports ratio expressed in NPV terms and 20 percent to 25 percent for the ratio of debt service to exports. Of course, other factors play an important role, and while countries with indicators above these thresholds may be more likely to encounter debt-service difficulties, it is also true that countries that have had debt-service difficulties and accumulated arrears or rescheduled had widely differing debt burdens. Thus, other country-specific "vulnerability factors," such as the concentration and variability of exports, the fiscal burden of external debt service, external debt in relation to GDP, the resource gap, the level of international reserves, and the burden of private sector debt, would need to be taken into account in determining whether to target the lower or the upper end of the two ranges.

In addition, for countries with very open economies (an export-to-GDP ratio of at least 40 percent) and making strong efforts to generate revenue (with a minimum threshold of fiscal revenue in relation to GDP of 20 percent) an NPV debt-to-export target below 200 percent at the completion point can be considered. For countries meeting these two openness and fiscal revenue thresholds, the NPV debt-to-export target will be set at a level that achieves a 280 percent ratio of the NPV of debt to revenue at the completion point. This modification of the interpretation of the Initiative was agreed to ensure that a small number of very open economies were able to attain a sustainable external debt situation from a fiscal point of view.

\section{Some Key Features of the HIPC Initiative}

The HIPC Initiative is based on six guiding principles that have been endorsed by the Executive Boards of the IMF and the World Bank and by the Interim and Development Committees (see Figure 2 and the Annex for a more detailed description of the Initiative). These are (1) the Initiative should target overall debt sustainability case by case, thus providing a durable exit strategy from the rescheduling process; (2) action would be envisaged only 
after the debtor country has shown, through a track record, an ability to put to good use whatever debt relief would be provided; (3) new measures will build on existing mechanisms as far as possible; (4) additional action will be coordinated among all creditors involved, with broad and equitable participation; (5) actions by the multilateral creditors will preserve their financial integrity and their preferred creditor status; and (6) new external financing for the countries concerned will be on appropriately concessional terms.

The Initiative has been developed around the following key building blocks: (1) eligibility will be limited to IDA-only and ESAF-eligible countries that have established a strong track record of performance under adjustment programs supported by the IMF and the World Bank and that are not expected to achieve a sustainable external debt situation after the full use of traditional debt-relief mechanisms; (2) eligibility will be based on a debt sustainability analysis (DSA); at the decision point (after the first three-year track record), the staffs of the IMF and the World Bank will jointly recommend targets for the completion point (after the second threeyear track record) for the NPV of debt-to-exports ratio and the debt-service ratio based on this analysis within the ranges mentioned above after giving full consideration to the vulnerability indicators; (3) the country would need to meet performance criteria during the second stage to receive support under the Initiative; these criteria would include macroeconomic indicators, progress on key structural reforms, and social reforms (for example, improving basic health care and education, and reducing poverty); and finally (4) all relevant creditors will be expected to participate.

As regards burden sharing between creditor groups, the Boards of the Bank and the IMF as well as other multilateral creditors have broadly supported a proportional approach toward sharing the burden of costs of the HIPC Initiative between multilaterals and official bilateral and commercial creditors. Under this approach, the costs of the HIPC Initiative would be shared by bilateral and multilateral creditor groups in proportion to the present value of their outstanding claims at the completion point. For this calculation, the claims of bilateral creditors would be measured after the full application of traditional forms of debt relief, that is, Naples terms from Paris Club creditors involving a 67 percent NPV reduction on eligible debt, and at least comparable action by other bilateral and commercial creditors. This is the basis on which all cases currently considered (see below) have been prepared.

Paris Club creditors have also endorsed proportional burden sharing, flexibly interpreted, with multilateral creditors. Specifically, they have 


\section{First Stage} - Paris Club provides flow rescheduling on Naples terms, namely rescheduling of debt service on eligi-
ble debt falling due during the three-year consolidation period (up to $67 \%$ reduction on eligible maturities on a net present value (NPV) basis).

- Other bilateral and commercial creditors provide at least comparable treatment.

- Multilateral institutions continue to provide adjustment support in the framework of an IMF-and World-

Bank-supported adjustment program.

- Country establishes first three-year track record of good performance.

\section{Y \\ Exit}

- Either Paris Club stock-of-debt operation under Naples terms (up to $67 \%$ present value reduction of eligible debt) and comparable treatment by other bilateral and commercial creditors are adequate for the country to reach sustainability by the completion point-country not eligible for HIPC Initiative.

\section{Decision Point}

Eligible

- Or Paris Club stock-of-debt operation (on Naples terms) not sufficient for the country's overall debt to become sustainable by the completion point-country requests additional support under the HIPC Initiative and IMF and World Bank Boards determine eligibility.

\section{Second Stage}

- Paris Club goes beyond Naples terms to provide more concessional debt reduction of up to $80 \%$ in present value terms.

- Other bilateral and commercial creditors provide at least comparable treatment.

- Donors and multilateral institutions provide enhanced support through interim measures.

- Country establishes a second track record of good performance under IMF- and World-Banksupported programs.

\section{Completion Point}

- All creditors take coordinated action to provide sufficient assistance to reduce the country's debt to a sustainable level on the basis of proportional burden sharing (after the full use of traditional debt relief mechanisms).

- Paris Club provides deeper stock-of-debt reduction of up to $80 \%$ in present value terms on eligible debt.

- Other bilateral and commercial creditors provide at least comparable treatment on stock of debt.

- Multilateral institutions take action to reduce the NPV of their claims, taking into account

the assistance provided by nonmultilateral creditors and their own preferred creditor status.

\section{Borderline}

- Or for borderline cases, where there is doubt about whether sustainability would be achieved by the completion point under a Naples terms stock-of-debt operation, the country would receive further flow reschedulings under Naples terms.

If the outcome at the completion point is as projected, or better than projected, the country would receive a stock-ofdebt operation on Naples terms from Paris Club creditors and comparable treatment from other bilateral and commercial creditors.

If the outcome at the completion point is worse than projected, the country could receive additional support under HIPC Initiative, so as to be able to exit from unsustainable debt.

\section{CInternational Monetary Fund. Not for Redistribution}


indicated a willingness to provide debt reduction in NPV terms of up to 80 percent, on a case-by-case basis, with a flow rescheduling during the second stage, and a stock-of-debt operation (equivalent to an NPV reduction of up to 80 percent on eligible debt) at the completion point. Paris Club creditors have also indicated a readiness to consider carefully the appropriate coverage of debt subject to 80 percent NPV reduction to achieve debt sustainability. Other nonmultilateral creditors would be expected to provide debt relief on terms at least comparable with the Paris Club. Multilateral creditors for their part would provide assistance on a proportional basis (as defined above) in accordance with their own charters in a way that would preserve their preferred creditor status.

\section{Key Steps in Implementing the HIPC Initiative}

For those HIPCs that would require the full use of traditional mechanisms and enhanced assistance under the Initiative to achieve debt sustainability, the following key steps are envisaged:

- The first stage of the Initiative builds on the existing three-year track record needed to qualify for a stock-of-debt operation from Paris Club creditors (see the Annex for details). During this stage, the country establishes the required good track record of policy implementation and makes full use of the traditional debt-relief mechanisms (Naples terms rescheduling with 67 percent NPV reduction).

- As the country completes the first stage and reaches the decision point, the Executive Boards of the IMF and the World Bank would decide the country's eligibility for the Initiative on the basis of a comprehensive DSA agreed jointly by IMF and World Bank staff members and the country's authorities. The assessment would indicate whether the full application of traditional debt-relief mechanisms (Paris Club stock-of-debt operation on Naples terms involving a 67 percent NPV reduction with at least comparable action from official bilateral and commercial creditors) would be sufficient for the country to reach a sustainable level of debt by the completion point. There are three possible outcomes: (1) a country is deemed to have a sustainable external debt situation at the completion point, in which case the country would not be eligible for assistance under the Initiative and would request a stock-of-debt operation on Naples terms; (2) a country is considered to be a borderline case (see Figure 2 and the Annex), in which case it could request to defer a stock-of- 
debt operation by Paris Club creditors to the completion point and request a flow rescheduling on Naples terms during the second stage; and (3) a country is deemed to be eligible for assistance under the Initiative.

- In the last outcome, a preliminary HIPC Initiative document would be prepared jointly by IMF and World Bank staff members discussing eligibility, and recommending country-specific debt sustainability target ranges. ${ }^{4}$ Consistent with these targets and the assumed action by bilateral and commercial creditors, the IMF and World Bank staff members, after consultation with concerned creditors, would recommend the required action by multilaterals, which would be proportional to that provided by bilateral creditors as a group.

- During the second stage of the Initiative, Paris Club creditors would provide flow reschedulings involving up to 80 percent NPV reduction as needed on a case-by-case basis and commit to provide at the end of the second stage - the completion point - a stock-of-debt operation with NPV reduction of up to 80 percent, provided the adjustment program supported by the IMF and the World Bank is implemented satisfactorily. Other bilateral and commercial creditors would be expected to offer at least comparable terms for the flow rescheduling and for the stock-of-debt operation. Donors, bilateral creditors, and multilateral institutions would provide financial assistance in the form of grants and concessional loans. The World Bank would provide IDA grants and supplemental IDA allocations during the second stage.

- At the completion point, provided the country has met the performance criteria under the Initiative, the stock-of-debt operation (involving up to 80 percent debt reduction in NPV terms) committed to by Paris Club creditors would take effect and multilateral institutions would provide the committed reduction in the NPV of their claims proportional to that provided by bilateral creditors as a group - unless actual debt-service indicators fall outside the agreed target range. The IMF would provide assistance to a country at the completion point through a special ESAF grant or loan that would be paid into an escrow account and used to cover debt service to the IMF. The World Bank would provide assistance at the completion point via the HIPC

\footnotetext{
${ }^{4} \mathrm{~A}$ target range for the NPV debt-export ratio would be specified (plus or minus 10 percentage points of the target) to allow for some variability in the outcome without the need for creditors to adjust their committed action.
} 
Trust Fund. Most other multilaterals are currently seeking the appropriate institutional approvals to enable them to participate in the Initiative including, in many cases, via the HIPC Trust Fund.

- The six-year performance period under the Initiative would be implemented flexibly on a case-by-case basis, with countries receiving credit for already established track records in the first stage. Exceptionally, the second stage of three years might be shortened for countries that already have sustained records of strong performance.

- A key element of the Initiative would be the provision of external finance on appropriately concessional terms to prevent a buildup of future debt-service problems. ${ }^{5}$ Thus, the ESAF programs accompanying the stages of the HIPC Initiative would involve restrictive limits on all nonconcessional borrowing. Efforts would be made to build up the HIPCs' debt-management capacities to help avoid the future recurrence of excessive indebtedness. In this respect, private lenders would also be encouraged to exercise restraint.

- Support under the Initiative would remain available to countries embarking on adjustment programs supported by the IMF and the World Bank before end-2000.

\section{Progress Made in the HIPC Initiative}

The international financial community has made rapid progress in implementing the HIPC Initiative in the first two years since it was endorsed by the Interim and Development Committees of the IMF and World Bank. More than $\$ 6$ billion in nominal debt relief has already been committed to seven countries, equivalent to $\$ 3$ billion in present value terms (see Table 8 ).

Uganda was the first country to reach its decision point in April 1997 and its completion point in April 1998 under the HIPC Initiative. Uganda is receiving assistance equivalent to approximately $\$ 650$ million in nominal terms or 20 percent of its outstanding debt, which reduced Uganda's NPV of debt-to-exports ratio to 196 percent. The IMF has provided funds covering about $\$ 80$ million of debt service over the next nine years. Bolivia reached its decision and completion points in September 1997 and September 1998, respectively. Total nominal debt relief is about $\$ 760$ million. The NPV of debt-to-exports ratio is reduced to 218 percent, and the debt-service ratio

${ }^{5}$ Such problems should also be reflected in the current NPV debt-to-exports ratio. 
will be reduced from 26 percent in 1997 to about 19 percent in 1999. The delivery of assistance by the IMF and the World Bank will be front-loaded in view of Bolivia's heavy debt-service burden in the next few years. The IMF's assistance of $\$ 30$ million in debt-service relief will cover 20 percent of Bolivia's annual debt service to the IMF during 1998-2002.

In addition, seven other countries have reached their decision points and five of those have received commitments of assistance under the HIPC Initiative: Burkina Faso, Guyana, Côte d'Ivoire, Mozambique, and Mali. Debt relief committed to Mozambique under the Initiative was the largest so far, at nearly $\$ 3$ billion in nominal terms. This debt reduction was achieved through exceptional efforts by Paris Club creditors in providing assistance above 80 percent NPV of debt reduction on eligible debt, including the provision by Russia-Mozambique's largest creditor-of special treatment on post-cutoff-date debt, by bilateral donors in providing voluntary contributions to help close the financing gap, and by the IMF and World Bank in providing voluntary assistance in addition to their proportional share. Guyana and Côte d'Ivoire were eligible for assistance under the Initiative under the fiscal/openness criteria described earlier. Assuming continued good performance in programs supported by the IMF and the Bank, and assurances that other creditors will provide their share of debt relief, Guyana, Mozambique, and Mali would reach their completion points in 1999, Burkina Faso in 2000, and Côte d'Ivoire in 2001. Benin and Senegal reached their decision points in July 1997 and April 1998, respectively; it was determined that they faced sustainable debt burdens after Naples terms debt relief from Paris Club creditors and therefore did not require assistance under the HIPC Initiative.

\section{Conclusion}

The HIPC Initiative is not a panacea for all of the economic problems of the HIPCs. Even if, hypothetically, all of the external debts of the HIPCs were forgiven, most would still continue to need large-scale concessional external assistance; as noted earlier, currently their receipts of such assistance are much larger than their debt-service payments. Given their high levels of poverty and limited domestic resources available to meet the costs of social programs that address the needs of the poor, most HIPCs are likely to continue to be dependent on aid. The HIPC Initiative does not imply a cessation of aid to HIPCs: if it leads to withdrawal of aid, it will fail. However, given the pressures on aid budgets in major donor countries, which are likely to prevail in the foreseeable future, continuing aid will be 
most effective if it catalyzes private financial flows, particularly investment. There is a limit to the extent to which these flows can be debt creating, if future overindebtedness is to be avoided. This suggests a need for institution building that is essential for attracting private investment as well as for providing support for putting in place necessary infrastructure.

Some HIPCs also need to address problems of governance, particularly as they influence investor confidence, such as the establishment of appropriate commercial codes of conduct, functioning judicial systems, and the effective application of the rule of law. To attract foreign investors, who can transfer technology, HIPCs need to provide much more information in a transparent way, remove red tape, and strengthen legal systems-on such issues as property rights. They also need to improve their financial systems, including payment and settlement systems. HIPCs are competing with other countries in attracting such foreign investment, and given adverse investor perceptions, have to offer attractive combinations of rate of return relative to risk. ${ }^{6}$ All of these are difficult issues that are likely to take a long time to resolve even with the full support of the international community. Most of the HIPCs will need to continue to pursue adjustment and reform policies to meet the economic aspirations of their citizens for long after they have benefited from Naples terms stock-of-debt operations or from enhanced debt relief under the HIPC Initiative.

The HIPC Initiative is intended to complete the array of instruments available to the international community for dealing with debt problems of low-income countries. The Initiative deals with the external debt of HIPCs in a comprehensive way that involves all creditors, and thus establishes a new paradigm for international action. Not all HIPCs will need assistance under the Initiative in order to achieve sustainable debt levels. However, for the HIPCs for which traditional debt-relief mechanisms are unlikely to achieve debt sustainability, the Initiative involves a commitment by the international community to take such additional action as may be required to reduce the debt burden to sustainable levels, and for the country to exit from the rescheduling process, provided that it is prepared to adopt and pursue strong programs of adjustment and reform. The Initiative should eliminate debt as an impediment to economic development and growth and enable HIPC governments to concentrate on the difficult policies and reforms for achieving sustainable development.

${ }^{6}$ Risk can be reduced through such action as participation in investment insurance programs such as Multilateral Investment Guarantee Agency. 


\section{Annex. The HIPC Initiative}

At their meetings in September 1996, the IMF's Interim Committee and the $I M F$ and World Bank's Development Committee endorsed specific proposals put forward jointly by the IMF and the World Bank to address the problems of a limited number of HIPCs that follow sound policies, but for which traditional debt-relief mechanisms are inadequate to secure a sustainable external debt position over the medium term. The Committees requested the two institutions to proceed quickly with the implementation of the Initiative.

The Interim and Development Committees endorsed in September 1996 a program of action proposed by the Managing Director of the IMF and the President of the World Bank to resolve the debt problems of HIPCs. The HIPC Initiative represents a commitment by the international financial community to reduce to sustainable levels the external debt burden of an eligible country that successfully completes a period of strong policy performance. This would reinforce these countries' efforts toward macroeconomic adjustment and structural and social policy reforms and assure that a country's debt burden does not inhibit its capacity for sustained growth. Social development policies would be selected according to their importance in the debtor's reform program and effect on reducing poverty, including especially actions to improve basic health care and education. Procedures adopted for implementing the Initiative require all relevant creditors and donors to coordinate their action in the context of a number of steps to be taken at various stages, as outlined below and illustrated in Figure 2:

- First stage. Paris Club creditors will provide a flow rescheduling under Naples terms (up to 67 percent reduction of the NPV of eligible debt) along with comparable action by other bilateral and commercial creditors. Multilateral institutions and bilateral donors will continue to provide support under adjustment programs supported by the IMF and the World Bank. Countries would establish their first three-year track record of good performance.

- Decision point. Toward the end of the first stage, the IMF and the World Bank will agree with the country authorities on a DSA in consultation with other creditors concerned. Based on this analysis, if strong policies and a Paris Club stock-of-debt operation on Naples terms are sufficient to put the country in a sustainable external debt position within three years (completion point), the country would re- 
quest such a stock-of-debt operation and would not be eligible for assistance under the Initiative. Alternatively, if the assessment indicates that a country's overall debt burden will not be sustainable by the completion point, it will be deemed eligible for and may request support under the Initiative. In borderline cases, the country may defer the stock-of-debt operation and request a further flow rescheduling under Naples terms and would be assured of additional action at the completion point, if needed to achieve debt sustainability.

- Second stage. For countries that are deemed eligible for support under the Initiative, the Paris Club-along with other bilateral and commercial creditors-will provide, on a case-by-case basis, flow reschedulings on more concessional terms involving an NPV reduction on eligible debt of up to 80 percent in present value terms. The country would establish a further three-year track record of good performance under adjustment programs supported by the IMF and the World Bank during which time some of the exceptional assistance committed by multilateral creditors could be provided, in addition to the flow rescheduling on enhanced terms agreed with nonmultilateral creditors.

- Completion point. The Paris Club will provide, along with other bilateral and commercial creditors, on a case-by-case basis, a stock-of-debt reduction of up to 80 percent in present value terms on eligible debt. Multilateral institutions will take proportional action to that provided by bilateral creditors as a group for the country to reach a sustainable debt situation, while ensuring broad and equitable participation by all creditors.

\section{Eligibility}

The Initiative would be open to all HIPCs that pursue programs of adjustment and reform supported by the IMF and the World Bank before October 1998, after which the Initiative would be reviewed and a decision made whether it should be continued. ${ }^{7}$ To qualify for exceptional assistance under the Initiative, countries would have to be eligible under ESAF and IDA-only and face an unsustainable debt situation after the full application of traditional debt-relief mechanisms and would have to demonstrate an appropriate track record of adjustment and reform. Whether or not a particular country

${ }^{7}$ This review was completed in September 1998, and the Executive Boards of the IMF and World Bank decided to extend the "sunset date" to end-2000. 
would be eligible for action will be determined by the Executive Boards of the World Bank and the IMF at the decision point, based on DSAs prepared jointly by the staff of both institutions in close cooperation with the country authorities.

\section{Track Record of Performance}

Debt is only one of the serious problems confronting the HIPCs and a track record of policy performance will be necessary to ensure a lasting solution not only to the country's debt problems but to its underlying economic difficulties; it will also be necessary in order to give confidence to creditors and donors that the exceptional assistance will be put to good use.

The required six-year performance period under the Initiative would be implemented flexibly on a case-by-case basis. The six countries (Benin, Bolivia, Burkina Faso, Guyana, Mali, and Uganda) that have already been granted a stock-of-debt operation by the Paris Club on Naples terms in 1995-96 can be considered to have established the track record required under the first stage of the Initiative. Other countries that have embarked on IDA- and ESAF-supported programs would be considered to be already engaged in the first stage. Exceptionally, the second stage of three years might be shortened for countries that have already established sustained records of strong performance (such as Bolivia and Uganda).

\section{Action by All Creditors}

All creditors are expected to participate in providing exceptional assistance beyond current mechanisms as required to reach debt sustainabilitythe fundamental objective of the Initiative. There is broad support from all creditor groups for a proportional approach, flexibly interpreted, toward sharing the costs of the HIPC Initiative between multilateral and official bilateral creditor groups. Under this approach, the costs of the HIPC Initiative would be shared by bilateral and multilateral creditor groups in proportion to the present value of their outstanding claims at the completion point. For this calculation, the claims of bilateral creditors would be measured after the full application of traditional forms of debt relief, that is, Naples terms from Paris Club creditors involving a 67 percent NPV reduction in eligible debt, and at least comparable action by other bilateral and commercial creditors. All creditors will be fully consulted on the action that would involve them under the Initiative. 
- Bilateral and commercial creditors: Paris Club creditors are ready to go beyond Naples terms and provide NPV debt reduction of up to 80 percent, on a case-by-case basis. They have indicated a readiness to consider carefully the appropriate coverage of debt subject to 80 percent NPV reduction to achieve debt sustainability. Consistent with current practice, debtors would seek treatment on debt owed to other bilateral and commercial creditors on terms at least comparable to those agreed with the Paris Club.

- Multilateral creditors will take proportional action to that provided by bilateral creditors as a group so that the country can achieve overall debt sustainability. The assistance provided by multilateral creditors should involve broad and equitable participation by all creditors and should preserve the financial integrity of the institutions and their preferred creditor status. Multilateral institutions will participate in the Initiative through action to reduce the NPV of their claims either through the HIPC Trust Fund or through parallel action.

- The World Bank is committed to take action during the second stagethrough the selective use of IDA grants and supplemental IDA allocations - and at the completion point. The principal vehicle envisaged for Bank participation, together with some other multilateral creditors, is a multilateral HIPC Trust Fund administered by IDA. The World Bank set aside $\$ 500$ million from its IBRD surplus as an initial contribution to the HIPC Trust Fund. Funds transferred by the World Bank to the HIPC Trust Fund will be earmarked to provide relief on debt owed to IDA. Additional transfers of IBRD net income to the HIPC Trust Fund are envisaged, as needed, for the World Bank's contribution to debt relief, subject to the IBRD income allocation framework and the approval of IBRD's Executive Directors and Board of Governors.

- IMF: Implementation of annual ESAF arrangements will form the economic policy basis for the IMF's participation in the Initiative, and the needed financial resources will come from the pool of resources for ESAF operations. However, in the context of the Initiative, special operations will take the form of grants or highly concessional loans on extended maturities that will be used to retire obligations falling due to the IMF and result in a reduction in the NPV of IMF claims on the debtor country. 
Table 1. Status of Paris Club Rescheduling Countries (As of October 30, 1998)

\begin{tabular}{lccc}
\hline $\begin{array}{l}\text { Low-Income } \\
\text { Countries }^{1}\end{array}$ & $\begin{array}{c}\text { Lower-Middle-Income } \\
\text { Countries }^{2}\end{array}$ & $\begin{array}{c}\text { Other Middle-Income } \\
\text { Countries }\end{array}$ & Total \\
\hline
\end{tabular}

Countries that graduated from reschedulings ${ }^{3}$

\begin{tabular}{|c|c|c|c|c|c|}
\hline${ }^{* *}$ Benin & $10 / 96$ & Dominican Rep. & $3 / 93$ & Algeria & $5 / 98$ \\
\hline$\cdots$ Bolivia & $10 / 98$ & Ecuador & $12 / 94$ & Argentina & $3 / 95$ \\
\hline "Cambodia & $6 / 97$ & Egypt & $6 / 94$ & Bulgaria & $4 / 95$ \\
\hline Gambia, The & 9/87 & El Salvador & 9/91 & Brazil & $8 / 93$ \\
\hline${ }^{* *}$ Haiti & $3 / 96$ & Ghana & $4 / 96^{4,5}$ & Chile & $12 / 88$ \\
\hline Malawi & $5 / 89$ & Guatemala & $3 / 93$ & Costa Rica & $6 / 93^{4}$ \\
\hline " Senegal & $6 / 98$ & Jamaica & $9 / 95^{4}$ & Croatia & $12 / 95$ \\
\hline${ }^{* *}$ Uganda & $4 / 98$ & Kenya & $1 / 944.6$ & \multicolumn{2}{|c|}{ Macedonia, FYR 6/96 } \\
\hline \multirow[t]{6}{*}{${ }^{*}$ Vietnam } & $12 / 93^{4}$ & Morocco & $12 / 92$ & Mexico & $5 / 92$ \\
\hline & & Philippines & $7 / 94^{7}$ & Panama & $3 / 92$ \\
\hline & & Poland & $4 / 91$ & Romania & $12 / 83$ \\
\hline & & & & \multicolumn{2}{|l|}{ Trinidad and } \\
\hline & & & & Tobago & $3 / 91$ \\
\hline & & & & Turkey & $6 / 83$ \\
\hline
\end{tabular}

Number of countries

Countries with rescheduling agreements in effect

\begin{tabular}{|c|c|c|c|c|c|c|}
\hline \multicolumn{7}{|l|}{ "Bosnia/ } \\
\hline Herzegovina & $4 / 99$ & Gabon & $11 / 98$ & $\underline{\text { Russia }}$ & $3 / 99^{8}$ & \\
\hline +**Burkina Faso & $6 / 96$ & Indonesia & $3 / 00$ & & & \\
\hline * Cameroon & $8 / 00^{9}$ & Jordan & $2 / 99$ & & & \\
\hline${ }^{*}$ Central African & & Peru & $12 / 98^{8}$ & & & \\
\hline Rep. & $6 / 01$ & & & & & \\
\hline${ }^{* *}$ Chad & $8 / 98$ & & & & & \\
\hline${ }^{*}$ Congo, Rep. of & $6 / 99$ & & & & & \\
\hline "** Côte d'Ivoire & $8 / 01$ & & & & & \\
\hline "Ethiopia & $10 / 99$ & & & & & \\
\hline${ }^{* *}$ Guinea & $12 / 99^{9}$ & & & & & \\
\hline +**Guyana & $5 / 96$ & & & & & \\
\hline "*Madagascar & $11 / 99$ & & & & & \\
\hline${ }^{* *}$ Mali & $5 / 96$ & & & & & \\
\hline${ }^{* * *}$ Mozambique & $6 / 99$ & & & & & \\
\hline${ }^{* *}$ Nicaragua & $2 / 01$ & & & & & \\
\hline${ }^{* *}$ Niger & $6 / 99$ & & & & & \\
\hline${ }^{* *}$ Rwanda & $5 / 01$ & & & & & \\
\hline "*Tanzania & $11 / 99$ & & & & & \\
\hline "*Yemen, & & & & & & \\
\hline Rep. of & $10 / 00$ & & & & & \\
\hline "Zambia & $12 / 98$ & & & & & \\
\hline $\begin{array}{l}\text { Number of } \\
\text { countries }\end{array}$ & 19 & & 4 & & 1 & 24 \\
\hline
\end{tabular}


TABLE 1 (CONCLUDED)

\begin{tabular}{lccc}
\hline $\begin{array}{l}\text { Low-Income } \\
\text { Countries }^{1}\end{array}$ & $\begin{array}{c}\text { Lower-Middle-Income } \\
\text { Countries }^{2}\end{array}$ & $\begin{array}{c}\text { Other Middle-Income } \\
\text { Countries }\end{array}$ & Total \\
\hline
\end{tabular}

Countries with previous rescheduling agreements, but without current rescheduling agreements, which have not graduated from reschedulings

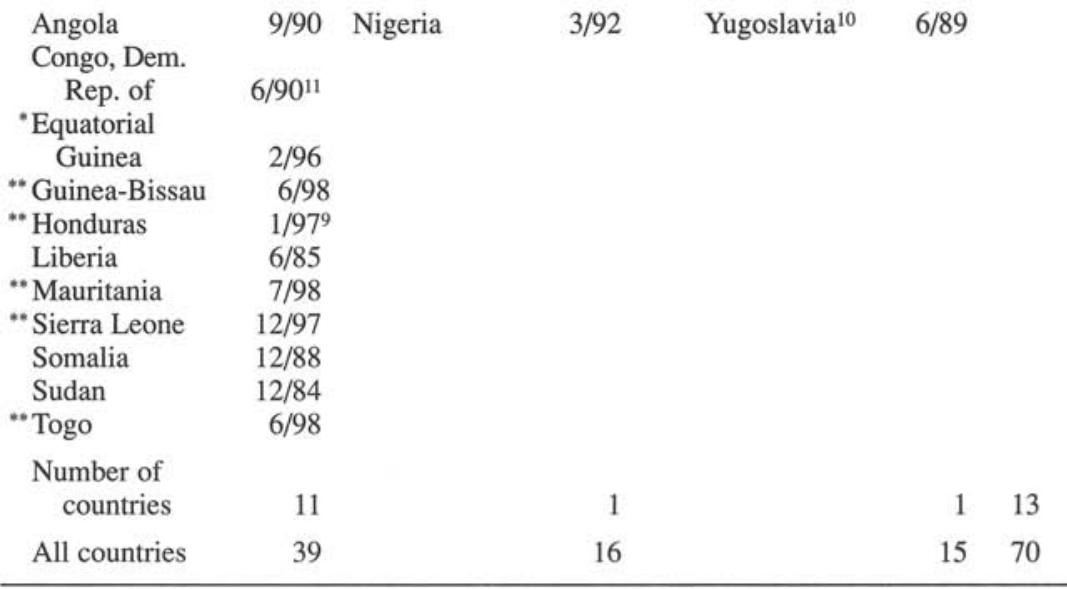

Source: Paris Club.

Notes: Includes agreements of Russia and Turkey with official bilateral creditors; stock treatment underlined. Dates refer to end of current or last consolidation period. In the case of a stock-of-debt operation, canceled agreements, or rescheduling of arrears only, date shown is that of relevant agreement.

${ }^{1 *}$ denotes rescheduling on London terms, ${ }^{* *}$ denotes rescheduling on Naples terms, and ${ }^{* * *}$ denotes rescheduling on Lyon terms. + denotes countries for which Paris Club creditors have indicated their willingness to provide debt relief on Lyon terms in the context of the HIPC Initiative.

${ }^{2}$ Defined here as countries that obtained lower-middle-income but not concessional terms with Paris Club reschedulings.

${ }^{3}$ For some countries, this inevitably represents an element of judgment: in certain circumstances, for example, if hit by an external shock, a country may need further reschedulings. Some of the low-income countries may be eligible for enhanced action under the HIPC Initiative.

${ }^{4}$ Rescheduling of arrears only.

${ }^{5}$ Limited deferral of long-standing arrears to three creditors on nonconcessional terms.

${ }^{6}$ Nonconcessional rescheduling at the authorities' request.

7The 1994 rescheduling agreement was canceled at the authorities' request.

${ }^{8}$ Agreement includes a reprofiling of the stock of certain debts at the end of the consolidation period.

${ }^{9}$ Involved debt relief of 50 percent in NPV terms.

${ }^{10}$ Former Socialist Federal Republic of Yugoslavia.

"Last rescheduling on Toronto terms. 
TABLE 2. HIPCs: INDICATORS OF EXTERNAL DEBT BURDEN ${ }^{1}$

\begin{tabular}{|c|c|c|c|c|c|c|c|c|}
\hline \multirow[b]{2}{*}{ Country $^{2}$} & \multirow{2}{*}{$\begin{array}{l}\text { NPV to } \\
\text { Exports } \\
\text { Ratio }^{3}\end{array}$} & \multirow{2}{*}{$\begin{array}{l}\text { Debt- } \\
\text { Service } \\
\text { Ratio }^{3}\end{array}$} & \multicolumn{3}{|c|}{$\begin{array}{l}\text { Percent Share in } \\
\text { Exports in } 1995 \text { of: }\end{array}$} & \multirow{2}{*}{$\begin{array}{l}\text { Variability } \\
\text { of Exports }{ }^{4}\end{array}$} & \multirow{2}{*}{$\begin{array}{l}\text { Noninterest } \\
\text { Current } \\
\text { Account } \\
\text { (In percent } \\
\text { of GDP) }{ }^{5}\end{array}$} & \multirow{2}{*}{$\begin{array}{c}\text { Reserve } \\
\text { Coverage } \\
\text { (In months } \\
\text { of imports) }\end{array}$} \\
\hline & & & Main & $\begin{array}{l}\text { Thr } \\
\text { product } p\end{array}$ & $\begin{array}{l}\text { hree main } \\
\text { products }\end{array}$ & & & \\
\hline Benin & & 9.7 & 35.9 & Cotton & 37.9 & 15.0 & -5.2 & -0.6 \\
\hline Bolivia & 270.2 & 25.4 & 12.2 & Zinc & 32.1 & 20.9 & -5.8 & 7.8 \\
\hline Burkina Faso & 275.2 & 18.0 & 38.7 & Cotton & 54.7 & 23.1 & -12.1 & CFA zone \\
\hline Cameroon & 352.7 & 56.5 & $\ldots$ & $\ldots$ & $\ldots$ & $\ldots$ & $\ldots$ & CFA zone \\
\hline Chad & 160.5 & 10.0 & 43.7 & Cotton & 67.7 & 13.6 & -16.0 & CFA zone \\
\hline \multicolumn{9}{|l|}{ Congo, Dem. } \\
\hline Rep. of the & 742.7 & 32.4 & 21.8 & Diamond & ds 45.7 & 26.6 & -4.5 & 0.1 \\
\hline Congo, Rep. of & 261.0 & 11.9 & 83.6 & Crude oil & il 93.1 & $\ldots$ & -39.6 & CFA zone \\
\hline Côte d'Ivoire & 360.6 & 17.9 & 28.6 & Cocoa & 47.5 & 10.5 & $\ldots$ & CFA zone \\
\hline \multicolumn{9}{|l|}{ Equatorial } \\
\hline Guinea & $\ldots$ & $\ldots$ & $\ldots$ & $\ldots$ & $\ldots$ & $\ldots$ & $\ldots$ & CFA zone \\
\hline Ethiopia & 599.7 & 33.8 & 36.8 & Coffee & 46.5 & 17.9 & -6.8 & 8.7 \\
\hline Ghana & 253.1 & 27.3 & $\ldots$ & $\ldots$ & $\ldots$ & $\ldots$ & $\ldots$ & $\ldots$ \\
\hline Guinea & 177.9 & 18.0 & 37.4 & Bauxite & 58.2 & 11.9 & -6.5 & 2.8 \\
\hline Guinea-Bissau & $1,293.2$ & 59.8 & 56.3 & Cashew & 64.0 & 30.8 & -11.2 & 2.8 \\
\hline Guyana & 180.4 & 14.6 & 19.9 & Sugar & 48.2 & 34.0 & -4.4 & 5.2 \\
\hline Honduras & 211.6 & 32.3 & 22.5 & Coffee & 46.3 & 13.3 & -2.7 & 2.7 \\
\hline Kenya & 147.1 & 24.3 & 7.3 & Tea & 15.7 & 18.3 & -1.7 & 3.6 \\
\hline \multicolumn{9}{|l|}{ Lao People's } \\
\hline Dem. Rep. & $\ldots$ & 6.8 & 19.9 & Wood & 54.7 & 69.8 & -17.3 & 2.6 \\
\hline Madagascar & 514.1 & 44.7 & 12.3 & Coffee & 25.6 & 20.2 & -3.8 & 2.3 \\
\hline Mali & 254.2 & 12.3 & 47.1 & Cotton & 75.1 & 20.6 & -13.7 & CFA zone \\
\hline Mauritania & 282.6 & 20.2 & 52.0 & $\ldots$ & $\ldots$ & $\ldots$ & -4.9 & 2.6 \\
\hline Mozambique & 780.8 & 30.3 & 15.5 & Prawns & 21.8 & 32.6 & -22.2 & 3.2 \\
\hline Nicaragua & 661.9 & 108.9 & 20.1 & Coffee & 39.8 & 30.3 & -16.5 & 1.0 \\
\hline Niger & 303.4 & 14.2 & 50.6 & Uranium & 69.3 & 19.3 & -9.7 & CFA zone \\
\hline Nigeria & $\ldots$ & $\ldots$ & $\ldots$ & $\ldots$ & $\ldots$ & $\ldots$ & $\ldots$ & $\ldots$ \\
\hline Rwanda & 745.9 & 49.6 & 55.8 & Coffee & 66.9 & 38.2 & -27.7 & 3.2 \\
\hline \multicolumn{9}{|l|}{ São Tomé and } \\
\hline Príncipe & $1,454.6$ & 26.6 & 50.2 & Cocoa & 80.3 & 11.6 & $\ldots$ & $\ldots$ \\
\hline Senegal & 147.7 & 15.7 & 17.8 & Fish & 32.2 & 11.7 & -5.0 & CFA zone \\
\hline Sierra Leone & 392.8 & 36.0 & 52.8 & Rutile & 97.3 & 18.6 & -14.7 & 1.4 \\
\hline Sudan & $\ldots$ & 194.3 & $\ldots$ & $\ldots$ & $\ldots$ & $\ldots$ & $\ldots$ & $\ldots$ \\
\hline Tanzania & 551.2 & 40.8 & 12.8 & Coffee & 26.8 & 32.7 & -13.7 & 1.9 \\
\hline
\end{tabular}


Public Sector

External Debt Service Payable
in 1996 as a Percent of: ${ }^{7}$

Government Government

revenue

17.3

...

17.0

93.5

22.9

223.9

27.2

...

...

26.8

29.1

32.6

68.9

42.4

70.7

27.8

8.7

102.6

17.4

12.6

50.8

134.6

25.5

...

38.5

127.4

30.4

22.2

…

63.6 expenditure

18.3

20.9

30.6

59.9

10.1

24.7

27.1

13.3

...

47.9

\begin{tabular}{|c|c|c|}
\hline $\begin{array}{l}\text { Fiscal Indic } \\
\text { as a Percent }\end{array}$ & $\begin{array}{l}\mathrm{rs}^{9} \\
\text { GDP }\end{array}$ & $\begin{array}{l}\text { NPV of } \\
\text { Public and Publicly } \\
\text { Guaranteed Debt }\end{array}$ \\
\hline grants & & $\begin{array}{c}\text { as Percent } \\
\text { of GDP }\end{array}$ \\
\hline
\end{tabular}

$\begin{array}{rrrr}12.2 & 5.4 & -6.7 & 50.7 \\ 17.4 & 2.4 & \ldots . & 44.6 \\ 11.2 & 7.3 & -8.7 & 30.5 \\ \ldots .0 & \ldots . & \ldots . . & \ldots . \\ 9.0 & 6.9 & 0.2 & 32.7\end{array}$

181.7

144.4

143.2

74.1

12.8

$$
6.3
$$

$-5.5$

...

7.1

...

7.9

3.1

…

11.1

$-10.2$

2.3

2.6

31.8

0.2

2.9

5.3

25.1

1.3

8.5

\begin{abstract}
3.8
\end{abstract}
$-1.1$

7.8

3.1

$-6.9$

12.7

7.1

2.2

8.6

7.8

$-9.9$

12.8

5.2

$-6.5$

7.4

4.0

0.6

...

7.8

16.3

..

\section{0}

13.9

10.4

23.5

$-4.7$

0.6

$3.7-1.2$

…

12.8

‥ $\quad \cdots$

$2.5-1.2$
33.5

199.9

160.5

71.7

45.3

43.1

90.6

47.6

134.1

158.7

205.9

42.5

...

38.3

342.8

42.0

58.7

...

112.7
Country

Benin

Bolivia

Burkina Faso

Cameroon

Chad

Congo, Dem. Rep. of the Congo, Rep. of Côte d'Ivoire Equatorial Guinea

Ethiopia

Ghana

Guinea

Guinea-Bissau

Guyana

Honduras

Kenya

Lao People's

Dem. Rep.

Madagascar

Mali

Mauritania

Mozambique

Nicaragua

Niger

Nigeria

Rwanda

São Tomé and Príncipe

Senegal

Sierra Leone

Sudan

Tanzania 
TABLE 2 (CONCLUDED)

\begin{tabular}{|c|c|c|c|c|c|c|c|c|}
\hline \multirow[b]{2}{*}{ Country $^{2}$} & \multirow{2}{*}{$\begin{array}{l}\text { NPV to } \\
\text { Exports } \\
\text { Ratio }^{3}\end{array}$} & \multirow{2}{*}{$\begin{array}{l}\text { Debt- } \\
\text { Service } \\
\text { Ratio }^{3}\end{array}$} & \multicolumn{3}{|c|}{$\begin{array}{l}\text { Percent Share in } \\
\text { Exports in } 1995 \text { of: }\end{array}$} & \multirow[b]{2}{*}{$\begin{array}{l}\text { Variability } \\
\text { of Exports }\end{array}$} & \multirow{2}{*}{$\begin{array}{l}\text { Noninterest } \\
\text { Current } \\
\text { Account } \\
\text { (In percent } \\
\text { of GDP) }\end{array}$} & \multirow{2}{*}{$\begin{array}{c}\text { Reserve } \\
\text { Coverage } \\
\text { (In months } \\
\text { of imports) }\end{array}$} \\
\hline & & & Main & \begin{tabular}{c}
\multicolumn{2}{c}{ Thre } \\
product $\mathrm{pro}$
\end{tabular} & $\begin{array}{l}\text { ree main } \\
\text { roducts }\end{array}$ & & & \\
\hline Togo & 211.8 & 17.7 & 19.5 & Phosphate & 46.0 & 22.4 & -5.0 & CFA zone \\
\hline Uganda & 293.8 & 18.1 & 68.4 & Coffee & 74.0 & 35.2 & -6.3 & 3.6 \\
\hline Vietnam & 86.8 & 6.8 & 14.1 & Crude oil & 28.7 & 38.8 & -10.3 & 2.1 \\
\hline \multicolumn{9}{|l|}{ Yemen, } \\
\hline Rep. of & 306.8 & 33.0 & $\ldots$ & $\ldots$ & $\cdots$ & $\ldots$ & $\ldots$ & $\ldots$ \\
\hline Zambia & 326.5 & 26.3 & 48.0 & Copper & $\ldots$ & 20.0 & -7.9 & 1.5 \\
\hline
\end{tabular}

Source: IMF staff estimates.

${ }^{1}$ All data refer to 1996 (1995/96) unless otherwise indicated.

${ }^{2}$ Excluded are those HIPCs for which no debt sustainability analysis has been prepared (Angola, Burundi, the Central African Republic, Liberia, Myanmar, and Somalia).

${ }^{3}$ Excluding workers' remittances. For the NPV ratio, present value of external debt service on disbursed public and publicly guaranteed debt in percent of the average of exports of goods and services over three years ending in 1996. For debt service ratio, one year of exports, 1996 is used.

${ }^{4}$ Defined as the standard deviation in export values over the ten-year period 1986-95 (1985/86-1994/95), in percent of the average. 
Public Sector

External Debt Service Payable

in 1996 as a Percent of: ${ }^{7}$

Government Government

revenue $^{8} \quad$ expenditure

\begin{tabular}{|c|c|c|}
\hline $\begin{array}{l}\text { Fiscal Indic } \\
\text { as a Percent }\end{array}$ & $\begin{array}{l}\mathrm{rs}^{9} \\
\text { GDP }\end{array}$ & $\begin{array}{l}\text { NPV of } \\
\text { Public and Publicly }\end{array}$ \\
\hline $\begin{array}{l}\text { Official } \\
\text { le grants }\end{array}$ & $\begin{array}{l}\text { Primary } \\
\text { balance }\end{array}$ & $\begin{array}{c}\text { as Percent } \\
\text { of } \text { GDP }^{7}\end{array}$ \\
\hline
\end{tabular}

Country

$\begin{array}{rrrrrrl}31.0 & 28.7 & 14.0 & 2.8 & -3.4 & 54.9 & \text { Togo } \\ 18.2 & 11.3 & 10.5 & 4.5 & -1.0 & 31.0 & \text { Uganda } \\ 11.4 & 11.0 & 19.6 & 0.6 & 1.2 & 26.2 & \begin{array}{c}\text { Vietnam } \\ \text { Yemen, } \\ \text { Rep. of } \\ 41.0\end{array} \\ 33.5 & \ldots & \ldots & \ldots & \ldots & \ldots & \ldots \\ \text { Zambia }\end{array}$

${ }^{5}$ Current account balance excludes interest and net official transfers.

${ }^{6}$ Imports of goods and services.

${ }^{7}$ After assumed debt rescheduling or relief, including Paris Club stock-of-debt operation on Naples terms, where applicable.

${ }^{8}$ Excluding grants.

${ }^{9}$ Central government. For Bolivia, Burkina Faso, the Lao People's Democratic Republic, Madagascar, Mali, Nicaragua, and Vietnam, government refers to general government. 


\begin{tabular}{|c|c|c|c|c|c|c|c|c|}
\hline & \multicolumn{2}{|c|}{$\begin{array}{c}\text { Total External } \\
\text { Debt (End-1996) }{ }^{1}\end{array}$} & \multirow{3}{*}{$\begin{array}{c}\text { Eligible } \\
\text { for Paris } \\
\text { Club Stock- } \\
\text { of-Debt } \\
\text { Operations on } \\
\text { Naples Terms }\end{array}$} & \multirow{3}{*}{$\begin{array}{l}\text { Debt to } \\
\text { Russia }\end{array}$} & \multicolumn{4}{|c|}{$\begin{array}{c}\text { Debt by Principal } \\
\text { Non-Paris Club Creditor Group }{ }^{3}\end{array}$} \\
\hline & \multirow{2}{*}{$\begin{array}{c}\text { Total } \\
\text { (In billions of } \\
\text { U.S. dollars) }\end{array}$} & \multirow{2}{*}{$\begin{array}{l}\text { Of which: } \\
\text { multilateral } \\
\text { (In percent) }\end{array}$} & & & \multirow{2}{*}{$\begin{array}{l}\text { Commercial } \\
\text { banks }\end{array}$} & \multicolumn{3}{|c|}{ Multilateral institutions } \\
\hline & & & & & & IMF & World Bank & Other \\
\hline Angola & 9.3 & 2.4 & & $\checkmark$ & & & & \\
\hline Benin & 1.6 & 60.8 & $\mathfrak{V}^{4}$ & & & & & \\
\hline Bolivia & 4.8 & 61.6 & $\mathfrak{V}^{4}$ & & & & & $\checkmark$ \\
\hline Burkina Faso & 1.2 & 95.8 & $\sqrt{4}^{4}$ & & & & & \\
\hline Burundi & 1.2 & 85.6 & & & & $\checkmark$ & $\checkmark$ & $\checkmark$ \\
\hline Cameroon & 8.1 & 22.8 & $\checkmark$ & & $\checkmark$ & & $\checkmark$ & \\
\hline Central African Rep. & 0.9 & 75.9 & $\checkmark$ & & & & & \\
\hline Chad & 1.0 & 83.4 & $\checkmark$ & & & & & $\checkmark$ \\
\hline Congo, Dem. Rep. of the & 9.9 & 27.7 & $\checkmark$ & & & $\checkmark$ & & $\checkmark$ \\
\hline Congo, Rep. of & 4.8 & 15.0 & & & $\checkmark$ & & & $\checkmark$ \\
\hline Côte d'Ivoire & 12.4 & 35.8 & $\checkmark$ & & $\checkmark$ & & $\checkmark$ & \\
\hline Equatorial Guinea & 0.3 & 49.4 & $\checkmark$ & & & & & \\
\hline Ethiopia & 5.1 & 52.8 & $\checkmark$ & $\checkmark$ & & & & \\
\hline Ghana & 5.2 & 70.9 & & & & $\checkmark$ & & \\
\hline Guinea & 3.0 & 54.0 & $\checkmark$ & $\checkmark$ & & & & \\
\hline Guinea-Bissau & 0.9 & 61.4 & $\checkmark$ & & & & $\checkmark$ & $\checkmark$ \\
\hline Guyana & 2.1 & 40.2 & $\mathfrak{V}^{4}$ & & & $\checkmark$ & & $\checkmark$ \\
\hline Honduras & 4.0 & 55.5 & $\checkmark$ & & & & $\checkmark$ & $\checkmark$ \\
\hline Kenya & 6.1 & 53.7 & & & & & $\checkmark$ & \\
\hline Lao People's Dem. Rep. & 2.2 & 34.8 & & $\checkmark$ & & & & \\
\hline
\end{tabular}




\begin{tabular}{|c|c|c|c|c|c|c|c|c|}
\hline Liberia & 1.4 & 51.2 & & & & $\checkmark$ & & \\
\hline Madagascar & 3.7 & 48.4 & $\checkmark$ & & & & & \\
\hline Mali & 3.0 & 53.7 & $\sqrt{4}$ & $\checkmark$ & & & & \\
\hline Mauritania & 2.3 & 47.1 & $\checkmark$ & & $\checkmark$ & & & $\checkmark$ \\
\hline Mozambique & 5.6 & 32.3 & $\checkmark$ & $\checkmark$ & & $\checkmark$ & $\checkmark$ & \\
\hline Myanmar & 5.2 & 25.4 & & & $\checkmark$ & & & \\
\hline Nicaragua & 5.3 & 30.4 & $\checkmark$ & $\checkmark$ & & $\checkmark$ & & $\checkmark$ \\
\hline Niger & 1.4 & 65.2 & $\checkmark$ & & & & & \\
\hline Nigeria & 28.2 & 17.9 & & & $\checkmark$ & & & \\
\hline Rwanda & 1.0 & 86.3 & & & & $\checkmark$ & $\checkmark$ & $\checkmark$ \\
\hline São Tomé and Príncipe & 0.3 & 71.9 & & & & & $\checkmark$ & $\checkmark$ \\
\hline Senegal & 3.6 & 63.8 & $\checkmark$ & & & & & \\
\hline Sierra Leone & 1.2 & 56.8 & $\checkmark$ & & $\checkmark$ & $\checkmark$ & & \\
\hline Somalia & 2.1 & 44.7 & & $\checkmark$ & & $\checkmark$ & $\checkmark$ & $\checkmark$ \\
\hline Sudan ${ }^{5}$ & 10.7 & 28.7 & & & $\checkmark$ & $\checkmark$ & & \\
\hline Tanzania & 6.3 & 50.9 & $\checkmark$ & & & & & \\
\hline Togo & 1.4 & 61.6 & $\checkmark$ & & & & & \\
\hline Uganda & 3.7 & 77.4 & $d^{4}$ & $\checkmark$ & & $\checkmark$ & $\checkmark$ & \\
\hline Vietnam & 23.9 & 4.1 & $\sqrt{6}$ & $\checkmark$ & $\checkmark$ & & & \\
\hline Yemen, Rep. of & 5.6 & 25.7 & & $\checkmark$ & & & & \\
\hline Zambia & 6.4 & 54.4 & $\checkmark$ & & & $\checkmark$ & & \\
\hline
\end{tabular}

Sources: World Bank Debtor Reporting System; and IMF staff estimates.

'Total public and publicly guaranteed debt.

$2 \sqrt{ }$ indicates whether Paris Club concessional rescheduling has taken place.

$3 \sqrt{ }$ indicates significant debt to the respective creditor.

${ }^{4}$ Stock-of-debt operation on Naples terms was agreed in 1995 or 1996.

sFigures for 1993.

${ }^{6}$ Exit rescheduling, no stock-of-debt clause. 


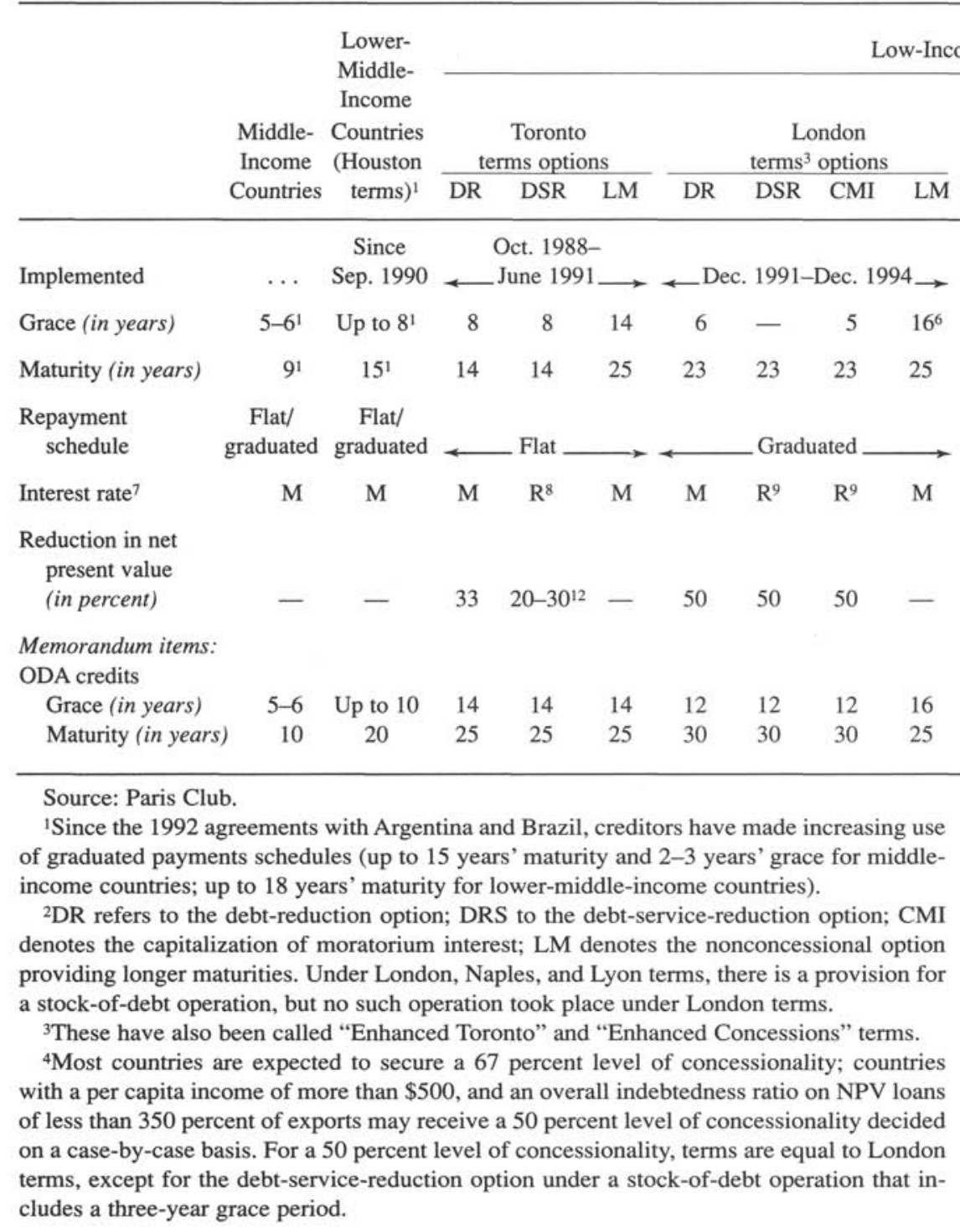


Countries $^{2}$

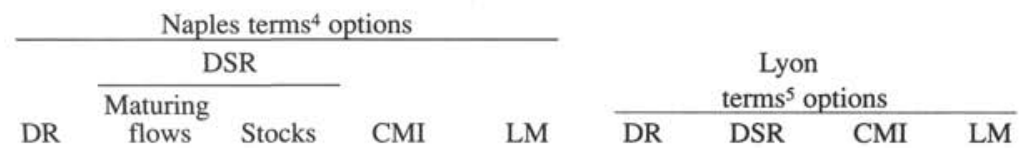

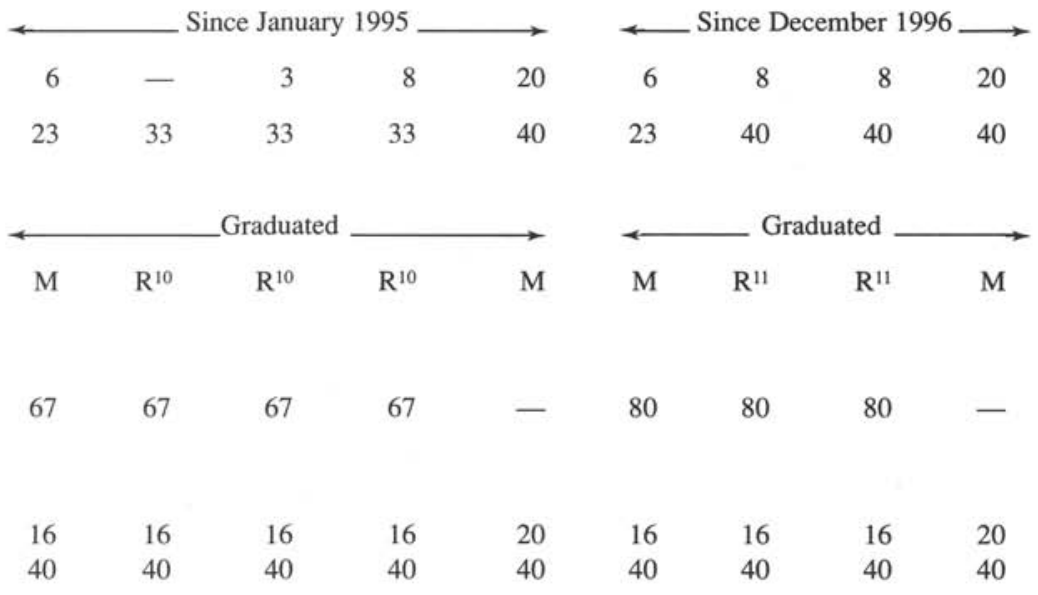

${ }^{5}$ These terms are to be granted in the context of concerted action by all creditors under the HIPC Initiative. They also include, on a voluntary basis, an ODA debt-reduction option.

${ }^{6}$ Fourteen years before June 1992.

'Interest rates are based on market rates $(\mathrm{M})$ and are determined in the bilateral agreements implementing the Paris Club Agreed Minute. $\mathrm{R}=$ reduced rates.

${ }^{8}$ The interest rate was 3.5 percentage points below the market rate or half of the market rate if the market rate was below 7 percent.

${ }^{9}$ Reduced to achieve a 50 percent NPV reduction.

${ }^{10}$ Reduced to achieve a 67 percent NPV reduction; under the DSR option for the stock operation, the interest rate is slightly higher, reflecting the three-year grace period.

"Reduced to achieve an 80 percent NPV reduction.

${ }^{12}$ The reduction of NPV depends on the reduction in interest rates and therefore varies. See footnote 8 . 
Table 5. Commercial Bank Debt- and Debt-Service-Reduction Operations, 1987-March 19971

(In millions of U.S. dollars)

\begin{tabular}{|c|c|c|c|c|c|c|c|c|c|c|}
\hline & \multicolumn{7}{|c|}{ Debt and Debt-Service Reduction (DDSR) ${ }^{2}$} & \multirow[b]{2}{*}{$\begin{array}{c}\text { Total Debt and } \\
\text { Debt-Service } \\
\text { Reduction/Debt } \\
\text { Restructured } \\
\text { (In Percent) } \\
\text { (6)] }(8)=(7) /(1)\end{array}$} & \multirow[b]{2}{*}{$\begin{array}{c}\text { Cost of } \\
\text { Reduction }\end{array}$} & \multirow[b]{2}{*}{$\begin{array}{c}\text { IMF } \\
\text { Contribution }\end{array}$} \\
\hline & $\begin{array}{c}\text { Restructured } \\
\text { Under DDSR } \\
\text { Operation } \\
\text { (1) }\end{array}$ & $\begin{array}{l}\text { Buyback } \\
\text { (2) }\end{array}$ & $\begin{array}{l}\text { Discount } \\
\text { exchange } \\
\text { (3) }\end{array}$ & $\begin{array}{l}\text { Principal } \\
\text { collateralized } \\
\text { par bond } \\
\text { (4) }\end{array}$ & $\begin{array}{l}\text { Other } \\
\text { bonds }^{4} \\
\text { (5) }\end{array}$ & $\begin{array}{l}\text { Prepayments } \\
\text { through } \\
\text { collaterali- } \\
\text { zation } \\
\text { (6) }(7)=\end{array}$ & $\begin{array}{r}\text { Total } \\
=\operatorname{sum}[(2) \text {. }\end{array}$ & & & \\
\hline & \multicolumn{10}{|c|}{ Concluded agreements } \\
\hline Albania (1995) & 371 & 146 & - & 225 & - & - & 371 & 100.0 & 96 & - \\
\hline Argentina (1992) & 19,397 & - & 2,356 & 4,291 & - & 2,739 & 9,386 & 48.4 & 3,059 & 987 \\
\hline Bolivia & 643 & 331 & 232 & 29 & - & 20 & 612 & 95.2 & 61 & - \\
\hline (1987) & 473 & 253 & 182 & - & - & 7 & 442 & 93.5 & 35 & - \\
\hline (1993) & 170 & 78 & 50 & 29 & - & 13 & 170 & 100.0 & 26 & - \\
\hline Brazil (1992) & 40,600 & - & 4,974 & 3,996 & 337 & 3,891 & 13,198 & 32.5 & 3,900 & - \\
\hline Bulgaria (1993) & 6,186 & 798 & 1,865 & - & 421 & 443 & 3,527 & 57.0 & 652 & 101 \\
\hline Chile (1988) & 439 & 439 & - & - & - & - & 439 & 100.0 & 248 & - \\
\hline Costa Rica $(1989)^{6}$ & 1,456 & 991 & - & - & 101 & 36 & 1,128 & 77.5 & 196 & - \\
\hline Dominican Rep. (1993) & 776 & 272 & 177 & - & - & 63 & 511 & 65.8 & 149 & - \\
\hline Ecuador (1994) & 4,522 & - & 1,180 & 826 & - & 596 & 2,602 & 57.5 & 583 & 85 \\
\hline Ethiopia (1996) & 230 & 230 & - & - & - & - & 230 & 100.0 & 18 & - \\
\hline Guyana (1992) & 69 & 69 & - & - & - & - & 69 & 100.0 & 10 & - \\
\hline Jordan (1993) & 736 & - & 84 & 111 & - & 117 & 312 & 42.5 & 118 & - \\
\hline Mauritania (1996) & 53 & 53 & - & - & - & - & 53 & 100.0 & 5 & - \\
\hline Mexico ${ }^{6}$ & 51,902 & - & 7,953 & 6,484 & - & 7,777 & 22,214 & 42.8 & 7,677 & 1,272 \\
\hline (1988) & 3,671 & - & 1,115 & - & - & 555 & 1,670 & 45.5 & 555 & - \\
\hline (1989) & 48,231 & - & 6,838 & 6,484 & - & 7,222 & 20,544 & 42.6 & 7,122 & 1,272 \\
\hline Mozambique (1991) & 124 & 124 & - & - & - & - & 124 & 100.0 & 12 & - \\
\hline Nicaragua (1995) & 1,099 & 1,099 & - & - & - & - & 1,099 & 100.0 & 88 & - \\
\hline Niger (1991) & 111 & 111 & - & - & - & - & 111 & 100.0 & 23 & - \\
\hline Nigeria $(1991)^{6}$ & 5,811 & 3,390 & - & 651 & - & 352 & 4,393 & 75.6 & 1,708 & - \\
\hline Panama (1995) & 1,914 & - & 38 & 98 & 353 & 82 & 571 & 30.0 & 92 & 30 \\
\hline Peru (1995) & 4,157 & 1,608 & 247 & 94 & 467 & 138 & 2,554 & 61.4 & 798 & 233 \\
\hline
\end{tabular}




\begin{tabular}{|c|c|c|c|c|c|c|c|c|c|c|}
\hline Philippines & 5,812 & 2,602 & - & 516 & 116 & 467 & 3,701 & 63.7 & 1,795 & 293 \\
\hline (1989) & 1,339 & 1,339 & - & - & - & - & 1,339 & 100.0 & 670 & 123 \\
\hline (1992) & 4,473 & 1,263 & - & 516 & 116 & 467 & 2,362 & 52.8 & 1,125 & 170 \\
\hline Poland (1994) & 9,989 & 2,424 & 2,427 & 796 & 74 & 611 & 6,332 & 63.4 & 1,933 & 283 \\
\hline São Tomé and Príncipe (1994) & 10 & 10 & - & - & - & - & 10 & 100.0 & 1 & - \\
\hline Senegal (1996) & 71 & 1 & - & 69 & - & - & 71 & 100.0 & 12 & - \\
\hline Sierra Leone (1995) & 230 & 230 & - & - & - & - & 230 & 100.0 & 32 & 一 \\
\hline Uganda (1993) & 152 & 152 & - & - & - & - & 152 & 100.0 & 18 & - \\
\hline Uruguay (1991) & 1,608 & 633 & - & 160 & - & 95 & 888 & 55.2 & 463 & - \\
\hline Venezuela (1990) & 19,700 & 1,411 & 511 & 2,012 & 471 & 1,639 & 6,043 & 30.7 & 2,585 & 883 \\
\hline Zambia (1994) & 200 & 200 & - & - & - & - & 200 & 100.0 & 22 & - \\
\hline \multirow[t]{2}{*}{ Total } & 178,368 & 17,324 & 22,044 & 20,358 & 2,340 & 19,066 & 81,131 & 45.5 & 26,354 & 4,167 \\
\hline & \multicolumn{10}{|c|}{ Pending agreements } \\
\hline \multicolumn{11}{|l|}{ Memorandum items: } \\
\hline Côte d'Ivoire $(1996)^{7}$ & 2,415 & 725 & 97 & - & 661 & 33 & 1,516 & 62.8 & 207 & $\cdots$ \\
\hline Vietnam $(1996)^{8}$ & 338 & 0 & 82 & 74 & - & 27 & 183 & 54.1 & 35 & - \\
\hline
\end{tabular}

Source: IMF staff estimates.

'Debt and debt-service reduction are estimated by comparing the present value of the old debt with the present value of the new claim, and adjusting for prepayments made by the debtor. The methodology is described in detail in Annex 1 of Private Market Financing for Developing Countries (Washington: International Monetary Fund, December 1992). The amounts of debt reduction contained in this table exclude debt extinguished through debt conversions. Year in parentheses refers to the date of the agreement in principle.

2The figure for debt-service reduction represents the expected present value of the reduction in future interest payments arising from the below-market fixed interest rate path on the new instruments relative to expected future market rates. The calculation is based on the estimated term structure in interest rates for U.S. treasury bonds at the time of agreement in principle.

${ }^{3}$ Excludes past due interest. Includes debt restructured under new money options for Mexico (1989), Uruguay (1991), Venezuela (1989), the Philippines (1992), Poland (1994), Panama (1995); the Philippines' (1989) new money option was not tied to a specific value of existing debt.

${ }^{4}$ Excludes prepayment of principal and interest through guarantees.

sCost at the time of operation's closing. Includes principal and interest guarantees, buyback costs, and, for Venezuela, resources used to provide comparable collateral for bonds issued prior to 1990. Excludes cash downpayments related to past due interest.

$\omega$ Includes estimated value recovery clauses.

${ }^{7}$ Assumes an allocation of 30 percent to the straight buyback option, 6 percent to the discount bond, and 64 percent to the Front Loaded Interest Reduction Bond.

${ }^{8}$ Assumes an allocation of 50 percent each to the par and discount bonds and no buyback.

\section{CInternational Monetary Fund. Not for Redistribution}




\begin{tabular}{|c|c|c|c|c|c|c|c|c|}
\hline & \multicolumn{2}{|c|}{ Annual Average } & \multirow[b]{2}{*}{1995} & \multirow{2}{*}{$\begin{array}{l}\text { Prov. } \\
1996\end{array}$} & \multicolumn{2}{|c|}{ Annual Average } & \multirow[b]{2}{*}{1995} & \multirow{2}{*}{$\begin{array}{l}\text { Prov. } \\
1996\end{array}$} \\
\hline & $1985-89$ & $1990-94$ & & & $1986-89$ & $1990-94$ & & \\
\hline & \multicolumn{4}{|c|}{$\longleftrightarrow$ In millions of U.S. dollars $\longrightarrow$} & \multicolumn{4}{|c|}{$\begin{array}{l}\text { In percent of } \\
\text { exports of goods and services }\end{array}$} \\
\hline Angola ${ }^{1}$ & 7 & 21 & 29 & 30 & 0.3 & 0.6 & 0.8 & 0.7 \\
\hline Benin & 39 & 78 & 73 & 60 & 9.5 & 14.5 & 12.6 & 10.3 \\
\hline Bolivia & 147 & 134 & 263 & 132 & 25.8 & 13.9 & 20.5 & 9.6 \\
\hline Burkina Faso & 41 & 85 & 109 & 76 & 10.2 & 20.2 & 29.7 & 20.1 \\
\hline Burundi $^{1}$ & 68 & 56 & 20 & 51 & 59.9 & 52.1 & 14.1 & 28.7 \\
\hline Cameroon & 76 & 73 & -45 & 125 & 3.7 & 3.0 & -1.6 & 4.7 \\
\hline Central African Rep. & 40 & 46 & 22 & 12 & 22.3 & 23.8 & 9.6 & 5.3 \\
\hline Chad & 29 & 76 & 59 & 118 & 17.6 & 33.6 & 22.0 & 46.7 \\
\hline Congo, Dem. Rep. of the ${ }^{1}$ & 139 & 72 & -1 & -103 & 6.7 & 1.8 & $\ldots$ & -5.0 \\
\hline Congo, Rep. of & 35 & 27 & -21 & 10 & 4.0 & 2.8 & -1.7 & 0.6 \\
\hline Côte d'Ivoire & -8 & 114 & 149 & 160 & -0.2 & 3.3 & 3.3 & 3.9 \\
\hline Equatorial Guinea ${ }^{1}$ & 8 & 8 & 1 & 6 & 24.1 & 15.7 & 1.1 & 6.2 \\
\hline Ethiopia & 75 & 200 & 175 & 238 & 10.1 & 25.6 & 15.4 & 22.5 \\
\hline Ghana & 189 & 187 & 150 & 106 & 20.9 & 16.5 & 9.3 & 6.9 \\
\hline Guinea $^{1}$ & 59 & 136 & 154 & 63 & 13.1 & 18.3 & 21.5 & 8.0 \\
\hline Guinea-Bissau $^{1}$ & 25 & 24 & 12 & 26 & 179.5 & 106.0 & 25.6 & 102.2 \\
\hline Guyana $^{1}$ & 19 & 53 & 7 & 26 & $\ldots$ & 6.3 & 1.1 & 3.7 \\
\hline Honduras & 25 & 107 & 47 & -38 & 0.4 & 9.3 & 2.6 & -2.1 \\
\hline Kenya & 89 & 64 & 32 & 32 & 4.0 & 2.8 & 1.1 & 1.1 \\
\hline Lao People's Dem. Rep. ${ }^{1}$ & 22 & 66 & 104 & 96 & 31.1 & 35.9 & 23.1 & 19.2 \\
\hline Liberia $^{1}$ & 15 & -2 & $\ldots$ & -43 & 4.0 & $\cdots$ & $\ldots$ & -8.3 \\
\hline Madagascar & 108 & 70 & 46 & 43 & 27.6 & 13.5 & 5.9 & 9.4 \\
\hline Mali & 62 & 91 & 158 & 93 & 16.5 & 16.8 & 24.1 & 14.9 \\
\hline Mauritania & 38 & 49 & 66 & 68 & 10.7 & 10.7 & 12.2 & 12.1 \\
\hline Mozambique & 54 & 164 & 188 & 314 & 26.8 & 45.1 & 38.8 & 57.3 \\
\hline
\end{tabular}




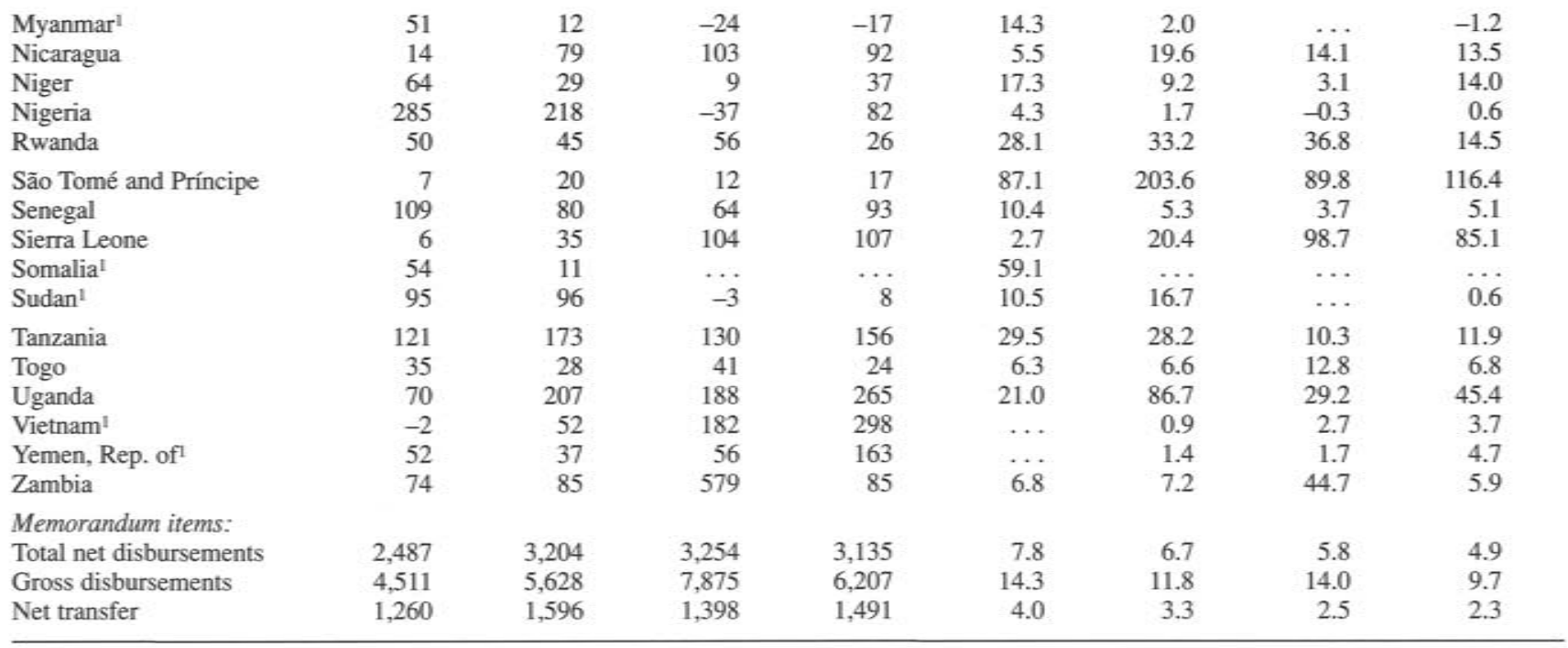

Sources: World Bank Debtor Reporting System; and IMF, International Financial Statistics.

Note: Disbursements on medium- and long-term public and publicly guaranteed debt, including to the IMF. The data are derived from the Debtor Reporting System except for the data on lending by the IMF.

${ }^{1}$ Annual average of net disbursements in percent of exports of goods and services is calculated only for selected years due to the lack of export data. 
Table 7. HiPCs: Net Concessional Flows, Debt Service Due and Paid ${ }^{1}$ (In percent of GNP)

\begin{tabular}{|c|c|c|c|c|c|c|c|c|c|c|c|c|c|c|c|}
\hline & \multicolumn{3}{|c|}{1990} & \multicolumn{3}{|c|}{1991} & \multicolumn{3}{|c|}{1992} & \multicolumn{3}{|c|}{1993} & \multicolumn{3}{|c|}{1994} \\
\hline & \multirow{2}{*}{$\begin{array}{l}\text { Net con- } \\
\text { cessional } \\
\text { flows }\end{array}$} & \multicolumn{2}{|c|}{$\begin{array}{c}\text { Debt } \\
\text { service }\end{array}$} & \multirow{2}{*}{$\begin{array}{l}\text { Net con- } \\
\text { cessional } \\
\text { flows }\end{array}$} & \multicolumn{2}{|c|}{$\begin{array}{c}\text { Debt } \\
\text { service }\end{array}$} & \multirow{2}{*}{$\begin{array}{l}\text { Net con- } \\
\text { cessional } \\
\text { flows }\end{array}$} & \multicolumn{2}{|c|}{$\begin{array}{c}\text { Debt } \\
\text { service }\end{array}$} & \multirow{2}{*}{$\begin{array}{l}\text { Net con- } \\
\text { cessional } \\
\text { flows }\end{array}$} & \multicolumn{2}{|c|}{$\begin{array}{c}\text { Debt } \\
\text { service }\end{array}$} & \multirow{2}{*}{$\begin{array}{l}\text { Net con- } \\
\text { cessional } \\
\text { flows }\end{array}$} & \multicolumn{2}{|c|}{$\begin{array}{c}\text { Debt } \\
\text { service }\end{array}$} \\
\hline & & Due & Paid & & Due & Paid & & Due & Paid & & Due & Paid & & Due & Paid \\
\hline Angola & 2.5 & 8.4 & 3.3 & 2.7 & 11.9 & 3.4 & 3.0 & 16.6 & 3.5 & 3.6 & 26.7 & 2.8 & 9.1 & 29.2 & 2.0 \\
\hline Benin & 11.8 & 6.1 & 2.1 & 11.7 & 3.3 & 1.6 & 11.1 & 2.6 & 1.2 & 9.5 & 2.7 & 1.6 & 12.9 & 3.5 & 2.8 \\
\hline Bolivia & 8.7 & 15.7 & 9.1 & 14.9 & 10.3 & 6.7 & 8.6 & 9.5 & 6.1 & 6.6 & 9.7 & 6.7 & 8.0 & 8.0 & 6.5 \\
\hline Burkina Faso & 8.3 & 1.8 & 1.3 & 12.3 & 2.9 & 1.7 & 11.3 & 1.5 & 1.2 & 12.6 & 1.9 & 1.3 & 10.3 & 1.5 & 1.5 \\
\hline Burundi & 19.1 & 3.8 & 3.8 & 15.9 & 3.3 & 3.4 & 22.7 & 4.1 & 3.7 & 18.4 & 4.5 & 3.9 & 31.4 & 4.5 & 4.6 \\
\hline Cameroon & 3.8 & 7.4 & 4.2 & 2.9 & 6.1 & 3.6 & 5.2 & 10.2 & 3.5 & 3.5 & 8.0 & 4.3 & 9.3 & 16.0 & 5.5 \\
\hline Central African Rep. & 15.3 & 3.8 & 2.3 & 13.3 & 2.3 & 1.2 & 10.3 & 2.8 & 1.2 & 11.4 & 3.1 & 0.8 & 15.5 & 9.1 & 2.7 \\
\hline Chad & 20.6 & 1.6 & 1.0 & 16.0 & 1.3 & 0.9 & 14.1 & 1.5 & 0.9 & 13.7 & 1.6 & 1.1 & 18.9 & 2.8 & 1.6 \\
\hline Congo, Dem. Rep. of the & 7.9 & 16.3 & 4.8 & 7.5 & 16.6 & 2.3 & 2.4 & 12.7 & 1.0 & 1.4 & 9.8 & 0.3 & 2.6 & 15.0 & 0.8 \\
\hline Congo, Rep. of & 6.8 & 50.7 & 21.8 & 2.4 & 30.6 & 12.4 & 2.1 & 22.6 & 6.3 & 3.6 & 22.4 & 5.9 & 29.0 & 131.2 & 47.8 \\
\hline Côte d'Ivoire & 6.5 & 29.1 & 13.7 & 6.2 & 24.4 & 15.2 & 5.7 & 19.5 & 12.8 & 6.8 & 18.1 & 12.5 & 25.4 & 45.3 & 23.4 \\
\hline Equatorial Guinea & 41.5 & 15.5 & 4.0 & 14.7 & 20.1 & 3.2 & 25.0 & 11.2 & 2.1 & 18.3 & 5.2 & 0.8 & 9.2 & 13.8 & 1.2 \\
\hline Ethiopia & 9.6 & 5.1 & 2.8 & 9.5 & 4.5 & 1.4 & 10.8 & 4.7 & 1.1 & 14.9 & 5.2 & 1.5 & 18.2 & 8.9 & 2.0 \\
\hline Ghana & 12.0 & 6.0 & 5.9 & 11.9 & 5.0 & 4.4 & 7.8 & 4.7 & 4.9 & 8.9 & 5.3 & 5.1 & 8.9 & 6.2 & 6.5 \\
\hline Guinea & 8.9 & 10.3 & 6.5 & 11.5 & 8.2 & 4.8 & 13.2 & 10.6 & 3.0 & 12.8 & 7.3 & 2.7 & 8.3 & 7.4 & 2.9 \\
\hline Guinea-Bissau & 39.5 & 19.1 & 3.6 & 39.8 & 21.7 & 3.6 & 29.0 & 23.0 & 4.1 & 21.6 & 19.8 & 1.9 & 28.9 & 28.6 & 2.8 \\
\hline Guyana & 71.0 & 154.1 & 107.5 & 107.2 & 73.6 & 47.8 & 32.2 & 56.6 & 38.6 & 29.5 & 40.7 & 24.8 & 12.2 & 36.0 & 21.2 \\
\hline Honduras & 12.0 & 25.1 & 14.2 & 23.6 & 14.1 & 11.2 & 11.0 & 16.8 & 12.4 & 9.7 & 17.5 & 11.8 & 8.6 & 16.2 & 14.9 \\
\hline Kenya & 16.7 & 9.6 & 9.7 & 10.1 & 10.4 & 9.4 & 7.6 & 10.2 & 8.8 & 10.6 & 15.2 & 12.3 & 7.9 & 21.0 & 13.7 \\
\hline Lao People's Dem. Rep. & 22.3 & 1.1 & 1.0 & 15.1 & 0.8 & 0.8 & 9.1 & 0.8 & 0.8 & 9.2 & 2.1 & 2.1 & 9.2 & 1.3 & 1.3 \\
\hline
\end{tabular}




\begin{tabular}{|c|c|c|c|c|c|c|c|c|c|c|c|c|c|c|c|}
\hline Liberia & 5.6 & 20.0 & 0.3 & 10.7 & 14.7 & 1.3 & 7.2 & 2.9 & - & 9.8 & 5.3 & 1.6 & 3.5 & 10.8 & 1.0 \\
\hline Madagascar & 18.1 & 13.3 & 7.4 & 17.4 & 15.9 & 6.5 & 10.3 & 14.0 & 3.5 & 9.2 & 10.1 & 2.4 & 12.3 & 22.9 & 3.3 \\
\hline Mali & 13.4 & 5.9 & 2.6 & 13.3 & 7.5 & 1.3 & 11.1 & 6.1 & 1.5 & 8.2 & 7.1 & 1.5 & 15.2 & 10.8 & 7.1 \\
\hline Mauritania & 15.6 & 21.9 & 15.5 & 15.0 & 18.6 & 9.1 & 15.6 & 22.5 & 7.5 & 31.4 & 40.2 & 14.3 & 21.3 & 19.5 & 10.8 \\
\hline Mozambique & 74.7 & 52.7 & 4.9 & 78.1 & 31.2 & 5.3 & 85.9 & 52.4 & 6.2 & 63.2 & 27.8 & 8.2 & 72.0 & 29.6 & 7.5 \\
\hline Myanmar & 1.2 & 3.0 & 0.6 & 0.8 & 2.8 & 0.7 & 0.7 & 2.7 & 0.4 & 0.4 & 2.5 & 0.7 & 0.7 & 3.4 & 1.0 \\
\hline Nicaragua & 50.8 & 98.0 & 1.6 & 69.5 & 157.0 & 41.0 & 43.1 & 66.0 & 7.9 & 16.8 & 21.8 & 9.4 & 22.1 & 106.3 & 13.3 \\
\hline Niger & 12.8 & 6.7 & 4.1 & 12.3 & 6.8 & 4.7 & 12.3 & 5.5 & 2.3 & 12.7 & 7.4 & 4.2 & 20.8 & 16.1 & 4.4 \\
\hline Nigeria & 0.7 & 21.8 & 11.4 & 0.6 & 18.4 & 9.9 & 0.5 & 23.1 & 13.8 & -0.2 & 18.2 & 5.8 & -0.3 & 17.8 & 5.9 \\
\hline Rwanda & 8.6 & 1.0 & 0.9 & 14.7 & 1.5 & 1.5 & 15.7 & 1.7 & 1.5 & 17.0 & 2.1 & 1.4 & 105.9 & 5.5 & 1.1 \\
\hline São Tomé and Príncipe & 90.0 & 20.8 & 5.9 & 130.9 & 18.0 & 4.0 & 114.4 & 24.3 & 6.8 & 104.2 & 40.9 & 7.7 & 159.4 & 37.2 & 11.5 \\
\hline Senegal & 12.7 & 7.3 & 5.9 & 8.2 & 8.0 & 5.9 & 9.3 & 5.9 & 3.6 & 6.5 & 6.1 & 2.2 & 14.3 & 12.5 & 5.3 \\
\hline Sierra Leone & 9.2 & 11.3 & 2.0 & 12.7 & 10.7 & 2.2 & 14.7 & 37.2 & 5.8 & 32.2 & 12.8 & 4.3 & 17.2 & 25.5 & 19.7 \\
\hline Somalia & 43.9 & 28.8 & 1.3 & 20.3 & 22.2 & - & 90.3 & 16.4 & - & 94.0 & 16.7 & - & 57.7 & 20.0 & - \\
\hline Sudan & 6.9 & 19.1 & 0.6 & 9.3 & 15.0 & 0.3 & 6.7 & 8.3 & 0.5 & 3.1 & 6.4 & 0.2 & 2.9 & 9.8 & - \\
\hline Tanzania & 37.1 & 21.8 & 7.4 & 34.5 & 20.9 & 7.6 & 41.7 & 31.6 & 9.5 & 41.2 & 35.0 & 10.0 & 34.8 & 25.8 & 8.2 \\
\hline Togo & 12.1 & 10.1 & 5.4 & 8.8 & 6.0 & 3.4 & 8.7 & 6.3 & 2.2 & 5.1 & 6.8 & 2.1 & 11.7 & 12.0 & 2.6 \\
\hline Uganda & 11.8 & 6.3 & 3.5 & 14.7 & 7.9 & 4.6 & 20.1 & 7.6 & 4.2 & 18.3 & 7.2 & 5.2 & 14.4 & 4.6 & 3.9 \\
\hline Vietnam & $\ldots$ & $\ldots$ & ... & -0.1 & 25.2 & 2.4 & 2.7 & 31.5 & 5.1 & 0.2 & 10.4 & 3.9 & 4.4 & 15.8 & 1.9 \\
\hline Yemen, Rep. of & 5.0 & 8.9 & 2.7 & 3.4 & 9.6 & 4.6 & 4.6 & 18.9 & 3.6 & 5.0 & 16.6 & 3.8 & 2.8 & 9.8 & 3.9 \\
\hline Zambia & 23.6 & 41.1 & 6.7 & 23.7 & 28.0 & 20.0 & 30.0 & 23.0 & 12.3 & 21.5 & 19.2 & 11.0 & 16.9 & 20.1 & 11.4 \\
\hline All HIPCs & 9.0 & 15.5 & 6.6 & 8.5 & 14.0 & 5.9 & 8.1 & 14.2 & 5.8 & 7.1 & 11.5 & 4.4 & 8.3 & 15.8 & 5.3 \\
\hline
\end{tabular}

Source: World Bank Debtor Reporting System.

${ }^{1}$ Net concessional flows consist of net concessional flows from multilateral and bilateral creditors and grants (excluding technical cooperation). Debt service due and debt service paid include payments related to the regularization of arrears. 


\begin{tabular}{|c|c|c|c|c|c|c|c|c|c|c|c|}
\hline \multirow{2}{*}{$\begin{array}{l}\text { Country } \\
\text { (In order of } \\
\text { expected } \\
\text { decision point } \\
\text { within groups) }\end{array}$} & \multirow[b]{2}{*}{$\begin{array}{c}\text { Decision } \\
\text { Point }\end{array}$} & \multirow[b]{2}{*}{$\begin{array}{c}\text { Completion } \\
\text { Point }\end{array}$} & \multirow{2}{*}{$\begin{array}{l}\text { NPV of } \\
\text { Debt-to- } \\
\text { Export } \\
\text { Target } \\
\text { (In percent) }\end{array}$} & \multicolumn{5}{|c|}{$\begin{array}{c}\text { Assistance at Completion Point } \\
\text { (In millions of U.S. dollars, present } \\
\text { value at completion point) }\end{array}$} & \multirow{2}{*}{$\begin{array}{l}\text { Percentage } \\
\text { Reduction } \\
\text { in NPV } \\
\text { of Debt }{ }^{1}\end{array}$} & \multirow{2}{*}{$\begin{array}{l}\text { Estimated Total } \\
\text { Nominal Debt- } \\
\text { Service Relief } \\
\text { (In millions } \\
\text { of U.S. } \\
\text { dollars) }\end{array}$} & \multirow{2}{*}{$\begin{array}{c}\text { Satisfactory } \\
\text { Assurances } \\
\text { from Other } \\
\text { Creditors }\end{array}$} \\
\hline & & & & Total & Bilateral & $\begin{array}{l}\text { Multi- } \\
\text { lateral }\end{array}$ & IMF & $\begin{array}{l}\text { World } \\
\text { Bank }\end{array}$ & & & \\
\hline \multicolumn{12}{|c|}{ Completion point reached } \\
\hline Uganda & Apr. 97 & Apr. 98 & 202 & 347 & 73 & 274 & 69 & 160 & 20 & 650 & Received \\
\hline Bolivia & Sep. 97 & Sep. 98 & 225 & 448 & 157 & 291 & 29 & 54 & 13 & 760 & Received \\
\hline \multicolumn{12}{|c|}{ Decision point reached and assistance committed by IMF and World Bank } \\
\hline Burkina Faso & Sep. 97 & Apr. 00 & 205 & 115 & 21 & 94 & 10 & 44 & 14 & 200 & Being sought \\
\hline Guyana & Dec. 97 & Feb. 99 & $107^{2}$ & 253 & 91 & 161 & 35 & 27 & 25 & 500 & Being sought \\
\hline Côte d'Ivoire & Mar. 98 & Mar. 01 & $141^{2}$ & 345 & 163 & 182 & 23 & 91 & $6^{3}$ & 800 & Being sought \\
\hline Mozambique & Apr. 98 & mid-99 & 200 & 1,442 & 877 & 565 & 105 & 324 & 57 & 2,900 & Being sought \\
\hline Mali & Sep. 98 & Dec. 99 & 200 & 128 & 37 & 90 & 14 & 44 & 10 & 250 & Being sought \\
\hline \multirow{2}{*}{\multicolumn{12}{|c|}{$\begin{array}{l}\text { Total assistance } \\
\text { provided/committed } \\
\text { ( } 7 \text { countries) }\end{array}$}} \\
\hline & & & & 3,078 & 1,419 & 1,657 & $285^{4}$ & 744 & 19 & 6,060 & $\cdots$ \\
\hline \multicolumn{12}{|c|}{ Debt judged sustainable } \\
\hline Benin & Jul. 97 & $\cdots$ & $\cdots$ & $\cdots$ & $\cdots$ & $\cdots$ & $\cdots$ & $\cdots$ & $\cdots$ & $\cdots$ & $\cdots$ \\
\hline Senegal & Apr. 98 & $\cdots$ & $\ldots$ & $\ldots$ & $\ldots$ & $\ldots$ & $\cdots$ & $\cdots$ & $\cdots$ & $\cdots$ & $\cdots$ \\
\hline
\end{tabular}

Sources: IMF and World Bank decisions, completion point documents, final decision point documents, and IMF staff calculations.

'In percent of NPV of debt at completion point, after full use of traditional debt-relief mechanisms.

${ }^{2}$ Eligible under fiscal/openness criteria; NPV of debt-to-exports target chosen to meet NPV of debt-to-revenue target of 280 percent.

${ }^{3}$ Nonreschedulable debt to non-Paris Club official bilateral creditors and the London Club, which was already subject to a highly concessional restructuring, are excluded from the NPV of debt at the completion point in the calculation of this ratio.

4Equivalent to SDR 212 million.

\section{CInternational Monetary Fund. Not for Redistribution}




\section{Glossary of Terms}

Bilateral creditors. These creditors are governments. Their claims are loans extended by, or guaranteed by, governments or official agencies, such as export credit agencies. Certain official creditors participate in debt reschedulings under the aegis of the Paris Club (see below).

Brady plan. Approach adopted in the late 1980s to restructure debt to commercial banks which emphasizes voluntary market-based debt- and debt-servicereduction (DDSR) operations. The cornerstone of DDSR operations is some combination of a buyback at a discount, and the issuance of "Brady bonds" by the debtor country in exchange for banks' claims. Such operations complement countries' efforts to restore external viability through the adoption of medium-term structural adjustment programs supported by the IMF and other multilateral and official bilateral creditors.

Completion point. A point at which the country concerned completes a second three-year track record of good performance under adjustment programs supported by the IMF and the World Bank, at which time additional measures will be taken to assist the country to reach a sustainable level of debt.

Debt sustainability. The position of a country when the net present value of debt (public and publicly guaranteed)-to-exports ratio and the debt service (on public and publicly guaranteed loans)-to-exports ratio are below certain countryspecific target levels within ranges of 200-250 percent and 20-25 percent, respectively. Country-specific targets within these ranges would be determined for the completion point in light of vulnerability factors, such as the concentration and variability of exports, and with particular attention to the fiscal burden of external debt service.

Debt sustainability analysis (DSA). A study jointly undertaken by staff of the IMF and the World Bank and the country concerned, in consultation with creditors, at the decision point. On the basis of this DSA the country's eligibility for support under the HIPC Initiative will be determined.

Debt service-to-exports ratio. Scheduled debt service (interest and principal payments due on public and publicly guaranteed debt during a year) for the same coverage of debt as in the NPV debt-to-exports ratio, expressed as a percentage of exports for that year.

Decision point. A point at which a HIPC completes its first (three-year) track record of good performance under adjustment programs supported by the IMF and the World Bank, and when, based on the debt sustainability analysis, a country's eligibility for the HIPC Initiative is determined. 
Heavily indebted poor countries (HIPCs). As used at present: a group of 41 developing countries, including 32 countries with a 1993 GNP per capita of $\$ 695$ or less and 1993 present value of debt to exports higher than 220 percent or present value of debt to GNP higher than 80 percent. Also includes 9 countries that have received concessional rescheduling from Paris Club creditors (or are potentially eligible for such rescheduling). However, this concept will evolve in the course of implementing the Initiative to include all countries eligible under the ESAF and IDA only that face unsustainable debt situations even after traditional debt-relief mechanisms are applied fully. Countries must also undertake adjustment programs supported by the IMF and the World Bank.

HIPC Initiative. Framework adopted jointly by the IMF and the World Bank for action to resolve the external debt problems of heavily indebted poor countries. The Initiative envisages comprehensive action by the international financial community, including the multilateral institutions, to achieve debt sustainability, provided a country builds a track record of strong policy performance.

HIPC Trust Fund. The HIPC Trust Fund will provide debt relief to eligible HIPCs on debt owed to participating multilaterals. It will either prepay, or purchase a portion of the debt owed to a multilateral creditor and cancel such debt, or pay debt service as it comes due. The HIPC Trust Fund will be administered by IDA and receive contributions from participating multilateral creditors and from bilateral donors. Contributions can be earmarked for debt owed by a particular debtor or to a particular multilateral creditor. Donors can also provide contributions to an unallocated pool and would participate in decisions regarding the use of these unallocated funds. The overall structure of the Trust Fund allows multilateral creditors to participate in the Trust Fund in ways consistent with their financial policies. It also addresses the resource constraints for certain multilateral creditors and the potential requirements of donors.

International Development Association (IDA). IDA is the concessional lending arm of the World Bank Group. IDA assistance is available to low-income member countries.

Multilateral creditors. These creditors are multilateral institutions such as the IMF and the World Bank, and other multilateral development banks.

Naples terms. Concessional debt-reduction terms for low-income countries approved by the Paris Club in December 1994 and applied on a case-by-case basis. Countries can receive a reduction of eligible external debt of up to 67 percent in net present value terms.

Net present value (NPV) of debt. The sum of all future debt-service obligations (interest and principal) on existing debt, discounted at the market interest rate. 
Whenever the interest rate on a loan is lower than the market rate, the resulting NPV of debt is smaller than its face value, with the difference reflecting the grant element.

Net present value (NPV) of debt-to-exports ratio. Net present value (NPV) of outstanding public and publicly guaranteed external debt at the end of the period, expressed as a percentage of exports of goods and services.

Official development assistance (ODA). ODA is defined by the Organization for Economic Cooperation and Development (OECD) as grants or loans extended by a government on concessional terms to developing countries with the promotion of economic development and welfare as the main objective.

Paris Club. Informal group of creditor governments mainly from industrial countries (i.e., the OECD) that has met on a regular basis in Paris since 1956 with the French Treasury providing the Secretariat. Creditors meet with debtor countries in order to agree with them on restructuring their debts as part of the international support provided to a country that is experiencing debt-servicing difficulties and is pursuing an adjustment program supported by an arrangement with the IMF.

Structural Adjustment Facility (SAF)/Enhanced Structural Adjustment Facility (ESAF). The SAF, established in 1986 and no longer operational, and the ESAF, established in 1987 and extended and enlarged in 1993, are the concessional loan windows of the IMF. These facilities are available to low-income member countries. 
This page intentionally left blank 
(All pamphlets have been published in English, French, and Spanish, unless otherwise stated)

45. Financial Organization and Operations of the IMF, by the Treasurer's Department. First edition, 1990. Fifth edition, 1998. Third edition also in Russian.

46. The Unique Nature of the Responsibilities of the International Monetary Fund, by Manuel Guitián. 1992.

47. Social Dimensions of the IMF's Policy Dialogue, by the staff of the IMF. 1995.

48. Unproductive Public Expenditures: A Pragmatic Approach to Policy Analysis, by the Fiscal Affairs Department. 1995.

49. Guidelines for Fiscal Adjustment, by the Fiscal Affairs Department. 1995.

50. The Role of the IMF: Financing and Its Interactions with Adjustment and Surveillance, by Paul R. Masson and Michael Mussa. 1995.

51. Debt Relief for Low-Income Countries: The HIPC Initiative, by Anthony R. Boote and Kamau Thugge. 1997. Revised 1999.

52. The IMF and the Poor, by the Fiscal Affairs Department. 1998.

Photographic or microfilm copies of all English editions, including numbers that are out of print, may be purchased direct from University Microfilms International, 300 North Zeeb Road, Ann Arbor, Michigan 48106, U.S.A. or from Information Publications International, White Swan House, Godstone, Surrey, RH9 8LW, England.

Copies of these pamphlets and information on earlier issues in the IMF Pamphlet Series may be obtained from:

International Monetary Fund, Publication Services

700 19th Street, N.W., Washington, D.C. 20431, U.S.A.

Telephone: (202) 623-7430

Telefax: (202) 623-7201

E-mail: publications@imf.org

Internet: http//www.imf.org 